\title{
A STUDY OF THE ILLINOIS SUPREME COURT*
}

$\mathrm{F}^{\mathrm{c}}$

OR over twenty-five years no systematic evaluation of the work and organization of the Illinois Supreme Court has been published. The last such study was made in 1920 when the judiciary received its share of attention at the time of the efforts to adopt a new constitution. ${ }^{x}$ Although issues of constitutional reform are once again being hotly debated, no such justification should be needed to examine the work of the Illinois Supreme Court. Rather, it is surprising that in the intervening years so little attention has been given to that court which is potentially the court of last resort for most of the litigation arising in Illinois.

Two major areas of research have furnished the data for this study. Within the first-the written opinions of the Court for the year 1946-47an attempt has been made to discover the bases of the Court's decisions and to investigate major developments in the substantive law. To this end, all cases for which opinions were handed down during the terms September 1946 through May $1947^{2}$ have been studied. Those were selected for discussion which either made a significant addition to the law of Illinois or which indicated the techniques of the Court in reaching decisions and writing opinions. An attempt has also been made to investigate the workings of the Court as an institution, including not only those procedures prescribed in the Constitution and by statute, but also rules of practice and the measures of convenience adopted by the justices.

Some of the questions guiding the inquiry are: What are the reasons for the unusual distribution of cases decided by the court? Are the opinions affected by the quantity and organization of the Court's work? Does the Court tend rigidly to follow precedent, or is there evidence of a shaping of the law for desired social ends? What are the techniques of statutory construction, and are they influenced by the Court's attitude toward administrative agencies and local government bodies? Finally, what did the $1946-47$ decisions do to change, fill the gaps in, or reaffirm the law in Illinois? At least tentative answers to most of these questions have been formulated. Some remained partially unanswered and must await additional investigation along suggested avenues of inquiry.

* This study was prepared by the Law Review staff and William H. Speck, Research Associate, University of Chicago Law School.

I Illinois Legislative Reference Bureau, Constitutional Convention Bulletin No. Io (I920).

a All opinions filed during the terms September I946 through May I947 and published through June 18, 1947 (397 Ill. 202) were studied. 
The results of the study are set forth in two parts. The first is an examination of the Court's leading opinions for $1946-47$. The second is an attempt to describe and evaluate the Court as a social institution.

\section{THE CASES}

For a state which contains the second largest city in the nation and the industrial and financial center of the midwest, the nature of the cases decided by the Supreme Court last year is startling. Yet the distribution of cases among the various categories is not dissimilar from that of previous years. ${ }^{3}$ The explanation for the large percentage of criminal and real property cases, the emphasis on public law, and the paucity of commercial cases, is to be found in the Illinois Constitution and the Civil Practice Act.

To alleviate the chronic overcrowding of the Illinois Supreme Court docket and thereby induce a more considered investigation of all cases heard before the Court, Section 75 of the Illinois Civil Practice Act allocates the bulk of appellate jurisdiction to intermediate bodies--the Illinois appellate courts. Direct appeal to the Supreme Court is reserved for certain specified instances. In the main, these instances are set forth in the Constitution of I87o: ". . . . appeals and writs of error shall lie to the Supreme Court in all criminal cases and cases in which a franchise or freehold or the validity of a statute is involved. ... ." Legislation has amplified these provisions, giving the right of direct appeal in all "criminal cases above the grade of misdemeanors," and in "cases in which a franchise or freehold or the validity of a statute or a construction of the constitution is involved," and in "cases in which the validity of a municipal ordinance is involved and in which the trial judge shall certify that in his opinion the public interest so requires and in all cases relating to revenue, or in which the state is interested as a party or otherwise. ... ""6

Despite the concededly substantial diversion of cases away from the Supreme Court which has actually resulted, the peculiarly anachronistic selection of cases for direct review has created a situation in which the Supreme Court is occupied with many trivial cases, while many important issues are finally resolved in the appellate courts. Almost 75 per cent of the cases coming to the Supreme Court arrive there by means of direct appeal. The result is that during the last term more than half the cases reaching the Court involved questions of criminal law or property, and fewer than 2 per cent of the cases were business cases. Table I shows a

3 Table 5 , infra, at I7I.

4 IIl. Const. Art. VI, §Ir.

s Ill. Rev. Stat. (I945) c. $38, \S 780 \frac{1}{2}$. $\quad{ }^{6}$ IIl. Rev. Stat. (I945) c. I10, $\S$ Ig9. 
comparison of the distribution of cases among the various categories in the Supreme Court and in the appellate courts.

It is apparent from the table that the cases occupying the greatest share of the Court's attention are not those appropriate for the highest court of an industrial and commercial state. Although this problem is a creature of the Illinois Constitution, the Court has attempted to alleviate it by narrowly construing the pertinent provisions of the Constitution. These attempts are discussed in the first section. Subsequent sections deal with criminal cases, public law, private law, and procedure and evidence.

TABLE 1

LEGAT RELATIONS GIVING RISE TO LITIGATION REACHING THE SUPREME COURT AND THE APPELXATE COURTS IN I946-47

\begin{tabular}{|c|c|c|c|}
\hline \multirow[b]{2}{*}{. } & \multirow{2}{*}{$\begin{array}{c}\text { SOPREME } \\
\text { CoURT* } \\
(\%)\end{array}$} & \multicolumn{2}{|c|}{ Appentate Courts $(\%) t$} \\
\hline & & $\begin{array}{c}\text { Full } \\
\text { Opinions }\end{array}$ & $\begin{array}{l}\text { Abstract } \\
\text { Opinions }\end{array}$ \\
\hline 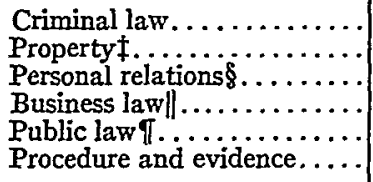 & $\begin{array}{r}37.9 \\
24.2 \\
10.0 \\
1.6 \\
23.8 \\
2.4\end{array}$ & $\begin{array}{r}5 \cdot 4 \\
25.9 \\
35 \cdot 5 \\
24 \cdot 1 \\
5 \cdot 4 \\
3.6\end{array}$ & $\begin{array}{r}6.1 \\
23.6 \\
39.9 \\
21.7 \\
2.5 \\
6.1\end{array}$ \\
\hline
\end{tabular}

* See Table 5, infra, at I7r, for a more detailed six-year tabulation. $\dagger$ See Table 6, infra, at 172, for a more detailed tabulation. cases.

† Includes real property, trusts, wills and probate, and landlord and tenant

Includes torts, workmen's compensation, and domestic relations cases.

|| Includes corporations, partnerships, contracts, insurance, negotiable instruments, and fraudulent conveyances.

I Includes constitutional problems, local government bodies, unemployment compensation, state officials, elections, eminent domain, and taxation.

\section{A. APPELLATE JURISDICTION}

Even the less populous states have found it necessary to establish intermediate appellate courts to protect their highest courts from overcrowded dockets. Curiously, however, there has been the utmost diversity in the criteria employed as a basis for the distribution of jurisdiction. One commentator has noted that "there is not a single question or field of the law, and not a single case which would not fall within the jurisdiction of an inferior appellate court in some states and of the highest court in others."7 As already indicated, the phraseology of Section 75 of the Illinois Civil Practice Act has its origin in Article VI, Section II of the Constitution of

7 Sunderland, Intermediate Appellate Courts, 6 Am. L. School Rev. 693, 694 (I930). 
I87o. Assuming that the categories selected for Supreme Court review accurately reflected the appellate review needs of a predominately agricultural community, it is doubtful that they satisfy contemporary requirements. ${ }^{8}$

An eloquent indication of this failure to meet present needs is the fact that more direct civil appeals to the Supreme Court have been predicated on the ground that a freehold is involved than on any other. 9 Despite all attempts to confine the scope of Supreme Court jurisdiction by strict construction of the phrase "cases in which a ... f freehold . . . is involved," and despite many previous rulings on identical issues, there has been repeated litigation of matters ostensibly well settled. Numerous decisions have established the general rule that a freehold is involved only where the necessary result of the judgment or decree is that one party gains and the other party loses a freehold, or where the title to a freehold is so put in issue by the pleadings that the determination of the case necessarily requires a decision on the ownership of the disputed property. ${ }^{\text {Io }}$

In Horner v. Winnebago County ${ }^{\text {II }}$ the plaintiff brought an action to recover damages for trespass to real property. The complaint alleged that the defendant had built a highway on the plaintiff's land. The defendant moved to dismiss on the ground that the plaintiff's action was barred by a prior decision that the plaintiff was not the owner of the land in question. The motion was granted, and on appeal the Supreme Court held that it did not have jurisdiction because a freehold was not involved. An analogous situation was presented by Aubry v. Supreme Liberty Life Insurance Co. ${ }^{\mathrm{I2}}$ decided the same day. There, the plaintiff brought suit against the defendant insurance company, alleging that she was the owner of a parcel of real estate from I932 to I937. The relief sought was a judgment for rent for the four-year period beginning in I933. The defendant moved to dismiss on the ground that the present cause of action was barred by a prior foreclosure decree. Motion to dismiss was granted. On appeal it was held that a freehold was not involved so as to give the Supreme Court jurisdiction on direct appeal.

${ }^{8}$ An examination of the debates and proceedings of the 1870 Constitutional Convention fails to reveal specific reasons for the choice of these particular items. Ill. Const. Conv., Debates and Proceedings (1870).

9 Table 4 , infra, at $r 70$.

Io Neill v. Kimball, 387 Ill. 58, 55 N.E. 2d 52 (I944); Cohen v. Ogliss, 384 Ill. 353,5 I N.E. 2d 46r (r943); Joslyn v. Joslyn, 380 Ill. I8I, 44 N.E. $2 d 323$ (r942); Gaskin v. Smith, 375 Ill. 59, 30 N.E. 2d 624 (1940); Harper v. Sallee, 372 Ill. r99, 23 N.E. 2 d 27 (1939); Opdahl v. Johnson, 372 Ill. I80, 23 N.E. 2d 3I (I939); Hooper v. Wabash Auto Corp., 365 IIl. 30,5 N.E. $2 \mathrm{~d} 462$ ( 1936$)$.

Ir 396 Ill. 382, 7 I N.E. 2 d 698 (I947). $\quad$ I2 395 Ill. 584, 7I N.E. $2 d 48$ (r947). 
The determining factor in each of these cases is that the sole relief sought is a money judgment, the assault on title being only collaterally involved. While it is arguable that both of these cases might be embraced by the principle that a freehold is involved where a decision in the case entails as a prerequisite a decision as to the title of the property concerned, and while it is conceivable that even astute lawyers might have been misled by the ambiguity of the phrase, numerous precedents were available which should have dispelled any doubt as to the interpretation which has found favor with the Court. Unless title has been directly put in issue by the pleadings of the parties, pleas for money judgments consistently have been found not to involve a freehold for the purpose of direct Supreme Court review. ${ }^{13}$

In a related instance, the existence of a large body of precedent has similarly not prevented repeated application for review. In $M a N a b b v$. Schmieder ${ }^{14}$ the plaintiff, a judgment creditor, sought to redeem land of the judgment debtor from a sale under execution and sought to have certain deeds set aside so that the plaintiff might be permitted to sell the land in satisfaction of his prior judgment. The complaint was dismissed, and on appeal direct review by the Supreme Court was refused, because, if relief were granted, the plaintiff would be under no obligation to redeem the land, and the defendants, as owners of the record title, could have satisfied the decree by paying the plaintiff the amount of his judgment.

The holding in this case should have been no surprise to the litigants. It long has been the rule in Illinois that in a suit to redeem from a judicial sale, appeal cannot be taken directly to the Supreme Court on the ground that the plaintiff also seeks to set aside instruments conveying the premises to the defendants who purchased at the sale. ${ }^{15}$ The Court has pointed out that in these cases the relief sought is the right to redeem, and where the decree in favor of the plaintiff could only establish the right of redemption with the ultimate status of the freehold contingent upon its actual exercise it has refused to grant direct appeal. Whatever questions of title have arisen in such cases have been held to be only incidental to the right to redeem.

In Spies v. DeMayo ${ }^{16}$ the plaintiff brought suit to recover damages for

${ }^{23}$ Horner v. Winnebago County, 396 Ill. 382, 7 I N.E. 2d 698 (1947); Coburn v. Macke, 369 Ill. I06, I5 N.E. 2d 852 (1938); Kuhne v. Sanitary Dist. of Chicago, 285 Ill. I 29, I 20 N.E. 47 I (I918); Pleasant Hill v. Stark, 277 Ill. 302, I 5 N.E. I88 (I9x7).

${ }^{24} 396$ Ill. 92,7 x N.E. $2 d{ }_{4}$ (I947).

${ }^{25}$ Ziegler v. Perbix, 380 Ill. 264, 43 N.E. 2d 97 (I942); Joslyn v. Joslyn, 380 Ill. 18I, 44 N.E. $2 \mathrm{~d} 323$ (1942); Callner v. Greenburg, 372 Ill. 176,23 N.E. $2 \mathrm{~d} 29$ (I939).

${ }^{26} 396$ Ill. 25,72 N.E. 2 d 316 (I947). 
the reasonable value of oil produced from a tract of land. He contended that a warranty deed, absolute in form, which the defendants asserted was a mortgage, was an absolute conveyance of title. The trial court held that the warranty deed conveyed the property according to its tenor, that it was not a mortgage, and, further, that a small part of the land the plaintiff intended to convey was unintentionally omitted from the conveyance, and that the deed should be reformed to include this land. The Supreme Court held that a freehold was involved in the question as to whether the deed should be reformed, but in a dictum stated that the principal question (whether the instrument from the defendant's grantor was a mortgage or a deed) did not involve a freehold. This opinion clearly illustrates the rationale employed by the Court in accepting cases for review. Because reformation of the deed to include the omitted land would necessarily require an actual transfer of ownership, the case was held to involve a freehold. But the dictum disallows review of a suit to have an absolute deed declared a mortgage because the operation of the decree per se would not operate to divest the grantee of title. Assuming that the trial court declared the deed to be a mortgage, the act of redemption would still be required to transfer title.

Actually, however, it would appear that neither of these issues is of more significance than those involved in many other types of litigation which are not awarded direct review. The controversy over the reformation of the deed in the DeMayo case involved but a few rods of land and was neither central to the case nor important to the community, yet outmoded statutory and constitutional provisions required that it be reviewed by the highest court in the state. It is to minimize consideration of such trifles that the Court has been compelled to distill the legal refinements exemplified in these cases. That the Supreme Court must dedicate so large a portion of its energies to drawing fine distinctions in an effort to avoid consideration of problems that may not intrinsically be of great worth can hardly be regarded as salutary.

Despite the technical and severe distinctions which the Court has made, there are areas in which its rigor has been relaxed. In Pennell v. Osborn ${ }^{17}$ an action was brought to void, on grounds of fraud, an oil and gas lease permitting the lessee to enter the land for a primary term and as long thereafter as oil, gas, or other minerals were produced from the land. The Supreme Court took jurisdiction on direct appeal, holding that a freehold was involved. This ruling is consistent with previous decisions on this pre-

${ }^{17} 396$ Ill. 32,7 I N.E. 2 d $56(1947)$. 
cise point, ${ }^{18}$ the theory being that as the term provided for in the lease might last for an indefinite period a freehold is involved. It might seem anomalous that the Court so easily concedes these cases to be within its jurisdiction, but its solicitude can perhaps be attributed to the importance which leases of this character are felt to play in the exploitation of the state's resources.

Analogous difficulties are presented by the cases purporting to involve constitutional questions. The facility with which counsel allege that parties to litigation have been deprived of constitutional rights has induced the Supreme Court to lay down stringent rules governing the review of such cases. These rules provide that a bona fide and debatable constitutional question must actually have been put in issue in the trial court, ${ }^{19}$ that the trial court must have passed upon it, ${ }^{20}$ and that such a determination must have been an integral part of the final decision in the case. ${ }^{2 x}$

People v. Brickey ${ }^{22}$ contains a restatement of the Court's requirement that to procure direct review there must be a sharper definition of issues than is contained in the mere blanket assertion that a statute is violative of constitutional rights. There must be a statement of the particular manner in which it is alleged to be unconstitutional. In this case appellant was fined $\$ 1,0 \infty$ and sentenced to eighteen months and one day in the county jail for a second violation of a criminal statute which provided, inter alia, that a person convicted for a second time of keeping a gaming house shall be fined not less than $\$ 500$ and imprisoned for not less than six months. The appellant brought error on the grounds that the statute was unconstitutional and that the punishment sought to be inflicted was so excessive as also to be unconstitutional. The unsupported allegation that the statute was unconstitutional was found insufficient to confer jurisdiction. It was further held that where a sentence is imposed within the limits of the statute, no constitutional question can be injected by merely assailing the statute as disproportionately severe. Strict enforcement of these

${ }^{18}$ Lambach v. Town of Mason, 386 Ill. 4I, 53 N.E. $2 d$ 60I (r944); Greer v. Carter Oil Co., 373 Ill. $x 68,25$ N.E. 2 d 805 (I940); Carter Oil Co. v. Liggett, 371 Ill. 482, 2I N.E. $2 d 569$ (1939); Watford Oil and Gas Co. v. Shipman, 233 Tl. 9, 84 N.E. 53 (Igo8); Bruner v. Hicks, 230 IIl. 536,82 N.E. 888 (I907).

I9 Vonesh v. City of Berwyn, 324 Ill. 483 , I55 N.E. 276 (1927); Whittington v. National Lead Co., 3 II IIl. 263 , I42 N.E. 474 (I924).

${ }^{20}$ Village of Niles Center v. Industrial'Comm'n, $37 x$ Ill. 622, 2I N.E. 2d 745 (I939); Holsman v. Campbell Realty Co., 37 r Ill. 6r4, 2 I N.E. 2d 744 (1939); People v. Fuller, 369 Ill. 492, I7 N.E. $2 \mathrm{~d}$ I8 (1938).

${ }^{25}$ Western \& Southern Indemnity Co. v. Industrial Comm'n, 366 Ill. 240, 8 N.E. $2 d 644$ (1937); Grutzius v. Armour \& Co. of Delaware, Inc., 377 Ill. 447, 36 N.E. $2 d$ 707 (194r).

$z 396$ Ill. 140, 7 r N.E. 2 d 57 (1947). 
restrictions seems essential if any cases at all are to be denied direct appellate review by the Supreme Court. The bias of the losing participant almost invariably encourages him in the belief that the unfavorable decree is "unconstitutional." As in the freehold cases, despite the efforts of the Court to clarify its position and thus to effectuate the policy of limiting direct appellate review, litigants persist in trying to avoid the consequences of these rules of exclusion. And these attempts in themselves negate the purposes for which the limitations on direct review were originally formulated. The Court may spend almost as much time writing an opinion determining whether a constitutional question is involved as it would were it to decide the case on its merits.

In Tinkoff v. Northwestern University ${ }^{3}$ the plaintiffs, father and son, sought a writ of mandamus compelling the University to admit the son as a student. The trial court dismissed the case. Within thirty days following the order of dismissal, the plaintiffs sought to file an amended complaint, which, if successful, would have injected a constitutional question into the case. The motion to amend, however, was denied. The Supreme Court held that the refusal to permit filing of the amended complaint after final judgment was a procedural rather than a constitutional question, notwithstanding that the amended complaint attempted to introduce a constitutional question into the case. Presumably, the plaintiffs were bringing their appeal on the hypothesis that, had the trial court properly entertained their motion to amend, a constitutional issue sufficient to command Supreme Court review would have been raised. But the settled principle is that such questions must actually have been argued before the trial court and that the court must expressly have resolved the issue in its decision. Here the supposed constitutional matter not only was not passed on, but was never even incorporated into the record. The only point at issue was whether the trial court should have permitted amendment of the complaint, a question remote from any constitutional consideration.

Another source of confusion is the failure to distinguish between cases attacking a judgment involving the construction of a constitutional pro-vision and cases attacking the judgment because it is claimed that its enforcement will deprive one of the parties of his constitutional rights. Only in the former is a constitutional question involved for purposes of direct review. In Dube v. Allman ${ }^{24}$ an action was brought against the defendant for alleged violations by the defendant's lessees of city zoning ordinances. On appeal before the circuit court from an order of the board 
of appeals directing the building commissioner to abate the violation, evidence was introduced indicating that, prior to the occupancy of the present lessees, the defendant's husband had operated a factory on the same premises for more than forty years, and that the nonconforming use being made of the premises by the present lessees was the same as, and merely an extension of, the past use made by the former occupant. A section of the zoning ordinance permitted the continuance of such previously existing nonconforming use after the ordinance became effective. Nonetheless the circuit court found for the plaintiffs, sustaining the order of the board of appeals. On the appeal, based on an alleged violation of the due process clause, the Supreme Court held that since a section of the zoning ordinance conceded the right by which a nonconforming use may be continued, the primary question resolved itself into one of fact as to whether the same nonconforming use actually was involved, and that this is not a constitutional question and therefore not properly before the Supreme Court. That the Court continues to be plagued with large numbers of cases of this type is evidence of the resistance encountered in impressing parties that the Supreme Court is to exercise only highly selective appellate jurisdiction.

Traditionally, to avoid multiple appeals and thus reduce litigation, a general rule has developed permitting review only of final judgments, orders, and decrees. This rule has been codified in the Civil Practice Act. ${ }^{25}$ But neither precedent nor codification has been of much avail in discouraging parties from bringing appeals. Frequently the attempted appeal is so obviously counter to any definition of the notion of "final judgment" that in disallowing it the Court finds it necessary only to quote precedent. The defendant in People v. Hard $t^{26}$ was charged with malicious mischief. The trial court sustained the defendant's motion to quash the indictment. The appellate court reversed the trial court and remanded the cause with directions to proceed in accordance with the views expressed in the opinion of that court. The defendant sued out a writ of error to review the order of the appellate court. Merely citing two other opinions on the exact point involved, the Supreme Court dismissed the writ. Apart from the citation of previous decisions the Court deemed the point worthy of no further elucidation, apparently considering it obvious that remanding a cause with directions for further proceedings could under no view be regarded as terminating the litigation. The very order of the appellate court here meant that there was to be further trial of the issues, and in this situation,

$$
25 \text { III. Rev. Stat. (I945) c. r10, § } 20 \text { I. }
$$

$$
{ }^{26} 395 \text { IIl. } 552,70 \text { N.E. } 2 \text { d } 577 \text { (1946). }
$$


where the original record was to be preserved, as distinguished from cases remanded for new trial, any other interpretation by the Supreme Court would have been inconsistent with the whole notion of final judgments.

Strangely enough, the Court in Matthews v. Trinity Universal Insurance $\mathrm{Co}^{27}$ itself overlooked this obvious argument. The plaintiff filed suit to collect on the obligation of a $\$ 2,300$ bond. The trial court found for the defendant, and on appeal the appellate court reversed and remanded the case for further proceedings with directions to enter a judgment for the plaintiff, without specifying the amount of the award, if no new defense were raised. The Supreme Court rejected the appeal, holding that, under Section 75(2) of the Civil Practice Act, the controversy was in the class of cases where a certificate is required to show the jurisdictional amount involved. ${ }^{28}$ To accomplish this result the Court was compelled to make a forced application of this section where none of its provisions was directly applicable without an unusual construction. ${ }^{29}$ The obvious, and simplest, procedure for the Court, however, would have been, as in the Hardt case, to recognize that the judgment lacked finality and to deny review under the provisions of Section 77 .

The recurrent theme implicit in the foregoing cases is the existing need for procedural reforms capable of reducing the appellate load of the Supreme Court, while at the same time complying with the requirements of the state constitution. Remedial steps should also be directed toward giving the Court the opportunity to broaden the exercise of its discretionary appellate jurisdiction, so that important principles of law might be defined by the state Supreme Court, rather than, as is now frequently the case, by inferior courts.

Unhappily, not only is current legislation not adequately designed to effectuate these ends, but the Court itself has formulated a principle not consonant with these objectives. This principle is that if a case involves an issue of which only the Supreme Court has jurisdiction and also contains issues properly presentable before the appellate court, if it is taken first to the appellate court, that court may properly assume jurisdiction,

${ }^{27} 397$ IIl. $x 74,73$ N.E. 2 d 284 (1947).

${ }^{28}$ Section 75 (2) of the Civil Practice Act limits Supreme Court appellate jurisdiction in such cases to those where judgment for the plaintiff has been entered in the amount of $\$ x, 500$ or more, where judgment is for the defendant but the appellate court certifies that an amount of $\$ x, 500$ is fairly involved in the claim of the plaintiff, or where leave to appeal is granted by the appellate court regardless of the amount involved.

${ }^{29}$ Explicitly under the terms of Section 75 (2) certification is required only when judgment is for the defendant, whereas in the instant case the appellate court reversed a judgment for the defendant and found for the plaintiff. It is difficult to see why the Court felt constrained to make sole reference to Section 75 (2) when none of its provisions is directly applicable. 
and the right to have the Supreme Court consider the question of which it would otherwise have had jurisdiction is waived. This principle has been held applicable to franchises, ${ }^{30}$ freeholds, ${ }^{3 \mathrm{~T}}$ the validity of ordinances, ${ }^{32}$ and constitutional questions. ${ }^{33}$ Probably one reason for the creation of this doctrine was the hope that the waiver provision would operate to cut down the number of instances in which direct review might be claimed. Actually it has served to motivate parties to make initial appeal to the Supreme Court in all cases where there is even the slightest doubt as to the existence of the right to such review. The operation of this rule puts the risk of forfeiture only on appellants going directly to the appellate court. It imposes no corresponding penalty for erroneous appeal to the Supreme Court. The inevitable outcome is that litigants, even those with but little hope of success, avail themselves of the opportunity to escape both risk and penalty by proceeding directly to the Supreme Court..$^{34}$

A strong argument can be made for the total elimination of direct review by the Supreme Court as of right in any case. The provisions of Section 75 of the Civil Practice Act are neither required by the Constitution nor beneficial in function. Article VI, Section II of the Constitution requires only that the Supreme Court take ultimate appellate jurisdiction of the prescribed categories. ${ }^{35}$ Provisions for direct appeal are a purely legislative product, and while much might be said in their behalf as mitigating the menace of double appeals, it is believed that the advantages flowing from the suggested revision preponderate. Usually, where litigants are required to pass through a number of appellate stages, fewer cases will get to the final appellate body. Since 1879 , cases involving misdemeanors have first gone to the appellate court, the constitutional provision being operative only to secure final review by the Supreme Court, and it has been found that such cases, in the main, do not reach the Su-

${ }^{30}$ Cratty v. Peoria Law Library Ass'n, 219 Ill. 516, 76 N.E. 707 (Ig06).

${ }^{32}$ Bennett v. Millard, 239 IIl. 332, 88 N.E. I65 (I909).

${ }^{32}$ Clark Teachers' Agency v. Chicago, 220 Ill. App. 319 (Igog).

${ }_{33}$ Central Union Tel. Co. v. Edwardsville, 269 U.S. 190 (1925); Cherry v. Aetna Casualty \& Surety Co., 372 IIl. 534, 25 N.E. 2d II (1939); People v. Terrill, 362 Ill. 61, I99 N.E. 97 (I935).

34 "An unauthorized appeal to this court delays the decision of the case until the record can be sent to the appellate court and the proper term of that court is reached. It is the duty of this court to determine whether it has jurisdiction, but the growing practice of bringing cases directly to this court upon the pretense that a constitutional question is involved, when the only matter in controversy is that the trial court has rendered an unjust or erroneous decision is not approved." Ockenga v. Alken, 376 Ill. 533, 34 N.E. 2d 7 II (I94r).

${ }^{35}$ Resa, Necessity of a Change Concerning Appeals in Illinois, 2 John Marshall L. Q. $16 r$, I65 (I936). 
preme Court. ${ }^{36}$ There is reason to believe that an equally desirable result would ensue if other privileged causes of action were treated similarly. The possibility of waste stemming from exposure to two successive appeals becomes much less formidable when there is substantial doubt that the second appeal will be taken.

Admittedly, the abolition of direct review by the Supreme Court will further encumber the appellate courts. The effect of a crowded docket, however, with the accompanying inclination toward haste and cursory examination is less serious in an intermediate appellate body than in a body whose time should be occupied with the most important judicial problems arising in the jurisdiction. Perhaps the most efficient organization of the Court's activities can be achieved only by the elimination of most appeals as of right through amendment of the Judiciary Article of the Illinois Constitution.

\section{B. CRMIINAI IAW}

Over one-third of the opinions handed down by the Illinois Supreme Court last year dealt with criminal cases. In addition, many petitions to the Court for original writs of habeas corpus were dismissed without opinion. A large majority of all decisions in criminal cases involved attempts by prisoners to secure hearings on alleged denials of constitutional rights in their convictions. Thus the size as well as the basic importance of the problem makes the need to furnish such hearings the most significant issue which the Court must face in the criminal law field.

Prior to 1943 , prison officials did not allow petitions to be mailed from state penitentiaries; prisoners who could not afford to employ counsel were therefore unable to bring their cases before the courts for review. However, in Ex parte Hull37 the United States Supreme Court held such a practice unconstitutional as a denial of equal protection of the laws in violation of the Fourteenth Amendment. The subsequent change in Illinois prison rules, permitting prisoners to send petitions to the courts, ${ }^{38}$ resulted in a flood of applications alleging unconstitutional convictions: petitions for writs of error, for writs of habeas corpus in the trial courts

${ }^{36}$ Dodd, Work of the Supreme Court of Illinois, 2 IIll. L. Rev. 207, 220 (I926); see Table 4 , infra, at ryo.

${ }^{37}{ }_{3}$ I2 U.S. 546 (I94I); cf. Cochran v. Kansas, $3 \times 6$ U.S. 255 (1942).

$3^{8}$ United States ex rel. Bongiono v. Ragen, 54 F. Supp. 973, 975 (Ill., I944), aff'd 146 F. 2d 349 (C.C.A. 7th, I944), cert. den. Bongiorno v. Ragen, 325 U.S. 865 (I945); United States ex rel. Foley v. Ragen, 52 F. Supp. 265, 267 (Ill., I943), rev'd 143 F. $2 d 774$ (C.C.A. 7th, 1944). 
and in the circuit courts in the counties of imprisonment, for original writs of habeas corpus in the Illinois Supreme Court, and a few motions in the nature of writs of error coram nobis.

Applications to the circuit or criminal courts for habeas corpus have been denied uniformly, almost always without calling for a response or appointing counsel to represent the petitioners. The large initial group of requests for leave to file petitions in the Illinois Supreme Court met a like fate, ${ }^{39}$ and such requests have diminished in importance since the decisions in People ex rel. Swolley v. Ragen ${ }^{40}$ and White v. Ragen. ${ }^{4}$ The opinions in the coram nobis and writ of error cases also show that dismissal of the petitions almost invariably does not involve a decision on the merits, but is based on procedural grounds. This virtually complete inability of prisoners to obtain hearings on their claims of denial of due process of law in their convictions calls for drastic revision of the machinery which Illinois affords for post-conviction hearings.

Since I932, the United States Supreme Court has interpreted the due process clause as requiring that certain minimum safeguards essential to fair trials be accorded to criminal defendants in state courts..$^{42}$ Further, the due process clause has been held to place a duty on the states to furnish some type of procedure by which prisoners' charges of violations of constitutional rights may be investigated. ${ }^{43}$ Most of the recent applications by Illinois convicts have relied upon these doctrines, alleging such grounds for relief as lack of adequate representation by counsel, ${ }^{44}$ use of

39 "In the last two terms of this Court, to April 2r, I945, 225 petitions for certiorari have been filed to review the denial by the Illinois Supreme Court of leave to file petitions for habeas corpus. From our examination of these applications, it appears that in no case did the Supreme Court of Illinois depart from the practice of denying leave to file without calling for a response and without opinion." White v. Ragen, 324 U.S. 760 at 762 n. I (1945).

${ }^{40} 390$ Ill. ro6, 6r N.E. 2 d 248 (1945), discussed at I2r infra.

4324 U.S. 760 (1945), discussed at I2r infra.

42 De Meerleer v. People of State of Michigan, 67 S. Ct. 596 (I947); Ashcraft v. Tennessee, 327 U.S. 274 (1946); see Canizio v. New York, 327 U.S. 82 (I946); Boskey and Pickering, Federal Restrictions on State Criminal Procedure, $1_{3}$ Univ. Chi. L. Rev. 266 (I946).

43 "A State must give one whom it deprives of his freedom the opportunity to open an inquiry into the intrinsic fairness of a criminal process even though it appears proper on the surface. .... Questions of fundamental justice protected by the Due Process Clause may be raised, to use lawyer's language, dehors the record." Carter v. Illinois, 329 U.S. I73, I75 (I946); cf. Mooney v. Holohan, 294 U.S. 103 (I935).

44 De Meerleer v. People of State of Michigan, 67 S. Ct. 596 (r947); Hawk v. Olson, 326 U.S. 27 I (1945); Rice v. Olson, 324 U.S. 786, 788 (I945); House v. Mayo, 324 U.S. 42, 46 (1945); Tomkins v. Missouri, 323 U.S. 485 (r945); Williams v. Kaiser, 323 U.S. 47 I (1945); Smith v. O’Grady, 312 U.S. 329, 334 (I94I); see Canizio v. New York, 327 U.S. 82 (I946); White v. Ragen, 324 U.S. 760,764 (I945). 
coerced confessions, ${ }^{45}$ and convictions on testimony which the prosecution knew to be false at the time of trial..$^{6}$

As soon as the Illinois penitentiary rules were altered to allow submission of petitions by inmates, the prisoners sought relief in the Illinois federal district courts. Almost all such petitions were dismissed, since "... . ordinarily an application for habeas corpus by one detained under a state court judgment of conviction for crime will be entertained by a federal court only after all state remedies available, including all appellate remedies in the state courts and in this Court by appeal or writ of certiorari, have been exhausted." 47 Petitioners who had not exhausted the available state remedies could secure a hearing in the federal courts only ".... in rare cases where exceptional circumstances of peculiar urgency are shown to exist." ${ }^{48}$ Most prisoners, unable to meet these requirements, turned to the state courts in their attempts to obtain relief, only to find that their troubles had scarcely begun. Under present procedures, it is nearly impossible to secure adjudication of the merits of alleged constitutional defects in judgments of conviction in Illinois courts; yet petitioners must present their applications for consideration seven to twelve times in order to escape the procedural maze of the state courts and to secure their initial hearings on the truth of their allegations in the federal courts.

Most of the prisoners, of course, have insufficient funds to employ counsel. Hence their petitions are filed pro se, and since prosecuted by the prisoners themselves, they are modeled on other allegations and briefs submitted by fellow prisoners. When the Illinois Supreme Court was thus deluged with applications for leave to file petitions for original habeas corpus writs, it adopted a procedure of denying such leave without requiring an answer, without appointing counsel to represent petitioners, and without giving reasons for its action. Petitioners' next step was to apply to the United States Supreme Court for writs of certiorari, a step which the Attorney General of Illinois had contended was essential to

45 Malinski v. New York, 324 U.S. 4 Or (I945); Ashcraft v. Tennessee, 327 U.S. 274 (I946), 322 U.S. I 43 (I944); Ward v. Texas, 3 I6 U.S. 547 (I942); White v. Texas, 3 Io U.S. 530 (r940); Chambers v. Florida, 309 U.S. 227 (I940); Brown v. Mississippi, 297 U.S. 278 (I936). The use of coerced confessions to which no objection is made at the trial usually occurs, of course, in cases where defendant has also been deprived of adequate representation by counsel.

${ }_{4}^{6}$ Ex parte Hawk, 32 I U.S. II4 (I944); Pyle v. Kansas, 3 I7 U.S. $2{ }_{3}$ (I942); Mooney v. Holohan, 294 U.S. ro3 (I935); see Lutz v. Ragen, 324 U.S. 760, 764 (I945).

47 Ex parte Hawk, 32 U.S. II4, II6 (1944).

$4^{8}$ Ibid., at II7; cf. United States ex rel. Bongiomo v. Ragen, 54 F. Supp. 973 (IIl., I944), aff'd I46 F. 2d 349 (C.C.A. 7th, I944), cert. den. Bongiorno v. Ragen, 325 U.S. 865 (r94.5). 
exhaustion of state remedies.49 When the Court granted certiorari in White v. Ragen, ${ }^{50}$ the Attorney General reversed his position, claiming that the Illinois Court's action had been based on the ground that habeas corpus was not the proper remedy in such cases, and that petitioners should have sought writs of error coram nobis..$^{5 x}$ This allegation, if sustained, would have placed the Illinois Court's denial of habeas corpus on a procedural and hence non-federal ground; the refusal to grant leave to petition for habeas corpus would not have violated due process of law, and the Supreme Court would have had to dismiss the petitions for certiorari. One week before oral argument in the White case, the Illinois Supreme Court departed from its usual practice in habeas corpus cases by making an "announcement" in connection with its denial of a prisoner's application..$^{32}$ The Court stated that habeas corpus was a proper remedy in Illinois only to consider assertions that the trial court lacked jurisdiction of the person of the defendant or of the subject matter in a criminal case. In the absence of such assertions, ".... the question whether errors or irregularities have occurred in the exercise of the jurisdiction can only be determined upon a writ of error." Furthermore, the Court announced, "... . any petition which raises questions of fact, only, will not be considered. This court does not try questions of fact." ${ }^{3}$ In view of this statement, the United States Supreme Court was unable to rule in the White case that the refusal of the Illinois Court to grant habeas corpus had not been based on the same procedural grounds. The availability of adequate non-federal grounds for the Tllinois decision allowed dismissal of the writ of certiorari without consideration of the relative scope of the habeas corpus and coram nobis remedies. The nominal effect of the opinion, then, was that petitioners need not apply to the United States Supreme Court for certiorari to review denial of habeas corpus by the Illinois Supreme Court in order to exhaust their state remedies. However, the full impact of the Swolley and White cases, taken together, is far greater. Despite the ambiguity of the "announcement" in the Swolley case, it seems that a criminal appellant need not apply to the Illinois Court for leave to petition for habeas corpus at all, since such application can no longer be considered as seeking an "available" state remedy. As a result of the Swolley

49 United States ex rel. Foley v. Ragen, I43 F. 2 d 774 (C.C.A. 7 th, I944), reply brief at I2; United States ex rel. Sogan v. Ragen, I46 F. 2d 5 I7 (C.C.A. 7th, I945), reply brief at 2.

${ }^{50} 324$ U.S. 760 (I945).

sx White v. Ragen, 324 U.S. 760 (1945), respondent's brief at 8-x4.

52 People ex rel. Swolley v. Ragen, 390 Ill. 106, 6I N.E. 2 d 248 (1945).

53 Thid., at I07, 248. 
case, this remedy has become a virtual dead letter. In the three opinions in the I946-47 terms which concerned such applications, habeas corpus was denied because the trial court had not lacked jurisdiction of the person and the subject matter. ${ }^{54}$

The remaining possibilities for seeking relief by habeas corpus lie in the circuit court of the county where the prisoner was convicted or where he is now imprisoned. Such petitions assumed new importance when the Illinois Court limited its own jurisdiction in the Swolley case. However, applications in the circuit courts were no more successful in securing hearings than they had been in the Supreme Court, and the invariable denial of petitioners' applications again led to petitions to the United States Supreme Court for writs of certiorari. Since the refusal of lower Illinois courts to grant habeas corpus is not reviewable by the Illinois Supreme Court, ${ }^{55}$ the lower courts are the "highest court[s] of a State in which a decision in the suit could be had." ${ }^{66}$ Hence, if the action by the circuit courts involved a constitutional question, the United States Supreme Court could properly have taken jurisdiction. Certiorari was granted in Woods v. Nierstheimer ${ }^{57}$ to consider whether such a constitutional deprivation of due process was involved in denying habeas corpus to petitioner..$^{58}$ Once again the Attorney General argued that coram nobis was the appropriate and exclusive remedy, and that denial of habeas corpus had therefore rested on non-federal grounds. The Supreme Court referred to the narrow scope of the habeas corpus remedy in Illinois and pointed out that under Illinois decisions the acts complained of by petitioner, although concededly violations of due process, had not ousted the trial court of its jurisdiction over the subject matter. Since a jurisdictional problem was not involved, the circuit courts could have denied the applications on this procedural ground, and the resulting lack of a federal question caused dismissal of the writs of certiorari.

The Woods decision removes the necessity for a petitioner, whose appli-

54 People ex rel. Hesley v. Ragen, 396 Ill. 554, 72 N.E. 2d 3 II (1947); People ex rel. Forsy the v. Nierstheimer, 396 IIl. I93, 7 I N.E. $2 \mathrm{~d} 62$ (I947), cert. den. Forsythè v. Nierstheimer, 67 S. Ct. 98I (r947); People ex rel. Thompson v. Nierstheimer, 395 Ill. 572, 7I N.E. 2d 343 (1947), cert. den. 67 S. Ct. 870 (I947).

s5 People ex rel. Maglori v. Siman, 284 Ill. 28, IIg N.E. 940 (rgr8); People ex rel. Magee v. McAnally, 22I IIl. 66, 77 N.E. 544 (1906).

${ }^{56}{ }_{14}$ Stat. 385,386 ( 1867$), 28$ U.S.C.A. $§ 344$ ( 1928$)$.

${ }^{57} 328$ U.S. 2 II (1946).

${ }^{8}$ Petitioner alleged that he had been beaten for four days until he consented to sign a paper which he later learned was a confession, that he was not allowed to consult with counsel before his trial, and that the public defender who was appointed as counsel entered a plea of guilty over petitioner's objections. Tbid., at 212. 
cation for habeas corpus in the Illinois circuit courts has been denied without opinion, to seek certiorari in the United States Supreme Court. But literal application of the Woods case and the Illinois law which it regards as controlling leads much further. The Swolley "announcement"s9 successfully prevented the United States Supreme Court from compelling the Illinois Court to grant hearings to all habeas corpus petitioners; although its language is ambiguous, it, together with the Woods case, may have the unanticipated effect of completely removing applications for habeas corpus from the state remedies which must be exhausted. Allegations of lack of counsel, coerced confessions, and state-suborned perjury, despite the fact that they constitute denials of due process of law, do not oust an Mlinois court of its jurisdiction. ${ }^{6}$ Since habeas corpus is limited in Illinois courts to jurisdictional problems, it is no longer an appropriate remedy for a criminal appellant to pursue. According to this view, petitioners can enter the federal district courts after seeking only two remedies in Illinois: writs of error and motions in the nature of writs of error coram nobis. Since the primary purpose of submitting petitions is naturally to secure a hearing on the facts of the allegations contained in those petitions, such a result would be a long step forward in granting a speedier remedy.

If the Illinois Court takes advantage of the uncertain language of the Swolley case to deny such a result, it can only do so by declaring that the field in which habeas corpus is a proper remedy is not limited to jurisdictional questions. But enlarging the scope of habeas corpus would remove the "adequate non-federal ground" which Illinois circuit courts now possess for the denial of habeas corpus, and the Woods case would no longer be law. The United States Supreme Court could then compel the state circuit courts to grant post-conviction hearings to prisoners who claim that their prosecutions violated the requirements of due process of law.

The Illinois Court seems to be postponing the inevitable decision as to whether it will or will not furnish any effective method for post-conviction hearings. The possibility of having to consider hundreds of petitions, the major portion of which may be fabricated or unmeritorious, is not an attractive one; but the Court could meet that possibility more effectively by an attempt to establish a weeding-out process and to afford hearings, than by closing off remedies gradually as they threaten to become available to petitioners.

59 People ex rel. Swolley v. Ragen, 390 Ill. I06, 6r N.E. 2d 248 (I945).

60 Ibid.; People ex rel. Thompson v. Nierstheimer, 395 Ill. 572, 7 I N.E. 2 d 343 (r947), cert. den. 67 S. Ct. 870 (I947). 
With petitions for original writs of habeas corpus in the llinois Supreme Court no longer available where the petition raises questions of fact, most criminal appellants have resorted to writs of error, which issue as of right to prisoners. ${ }^{6 x}$ In the last year, the Court indicated that a writ of error is an appropriate remedy to correct errors which would constitute a denial of due process. ${ }^{6_{2}}$ Although the twenty-year common-law limitation period which applies to writs of error ${ }^{63}$ has very little effect in barring prisoners from relief, other statutory requirements exclude the writ of error as an effective remedy. The criminal appellant is entitled automatically to the common-law record of the trial and conviction, which includes only the process and service, pleadings, orders, motions, affidavits, verdict, and judgment. ${ }^{64}$ If the prisoner wishes to present errors appearing only in a full record, he must also furnish a bill of exceptions and the trial transcript to the Court. But the transcript and bill must be obtained from the clerk of the trial court at the petitioner's expense, ${ }^{65}$ and, more important, they must be certified by the trial judge within fifty days after conviction. ${ }^{66}$ Any prisoner who lacked counsel at his trial is highly unlikely to learn of the fifty-day limitation in time. And many criminal defendants in Illinois are without counsel at the time of trial because the court is not under a duty to inform them of their right to counsel, ${ }^{67}$ unless they are involved in a capital case. ${ }^{68}$ In order to be assigned counsel the defendant must state on oath that he is unable to procure one. ${ }^{69}$

6x Ill. Rev. Stat. (I945) c. $38, \$ \S 769,77$ r.

62 People ex rel. Thompson v. Nierstheimer, 395 Ill. 572, 574, 7I N.E. 2d 343, 344 (1947), cert. den. 67 S. Ct. 870 (1947).

$6_{3}$ People v. Murphy, 296 Ill. 532, I29 N.E. 868 (I92x); see Fins, Survey of Illinois Appellate Procedure, 36 Ill. L. Rev. I7I, I80 (I94I).

6. IIl. Rev. Stat. (I945) c. I1o, \$259.36 (2).

65 Ill. Rev. Stat. (1945) c. $53, \S 81$.

${ }^{66}$ Ill. Rev. Stat. (I945) c. xIo, \$259.70 A.

67 People v. Van Horn, 396 Ill. 496, 72 N.E. 2d I87 (I947); People v. Creviston, 396 Ill. 78, 7 I N.E. 2 d 25 (I947); People v. Loftus, 395 Ill. 479, 70 N.E. 2d 573 (I946); People v. McElhaney, 394 Ill. 380 ,' 68 N.E. 2d 7I5 (I946); People v. Foster, 394 IIl. I94, 68 N.E. 2d 252 (r946); People v. Fuhs, 390 Ill. 67, 60 N.E. 2d 205 (r945), cert. den. Fuhs v. Illinois, 325 U.S. 858 (I945); People v. Corbett, 387 Ill. 4I, 55 N.E. 2d 74 (I944); People v. Parcora, 358 Ill. 448, т93 N.E. 477 (r934).

${ }^{68}$ Ill. Rev. Stat. (r945) c. $38, \$ 730$.

${ }^{69}$ Ibid. In People v. Bute, 396 Ill. 588, 72 N.E. 2 d 8I3 (I947), the Court effectively foreclosed any attack on the constitutionality of the statute by ruling that the question could not be raised in the Supreme Court if it had not first been raised in the trial court. Obviously, no defendant who knew of the statute and thus could challenge its constitutionality in the trial court would fail to request counsel in accordance with the statute. Thus the question cannot be raised at all. 
Thus the majority of criminal cases during the last year came up with a common-law record only, almost always prosecuted by the prisoner himself. When the court is confronted with the common-law record, its task is simple; any defendant who alleges denial of due process receives a theoretical hearing on the merits which is actually a mere formality. Typical of such cases is People v. McElhaney, ${ }^{70}$ in which petitioner alleged that he was not allowed to consult a lawyer or see his family from his arrest until the trial, that he was not given a preliminary hearing before a magistrate or given an opportunity to be released on bail, and that the State's Attorney wrongfully entered a plea of guilty after petitioner had refused to so plead. The absence of a bill of exceptions limited the Court to consideration of the common-law record; ${ }^{7 x}$ and the common-law record naturally contained nothing to support petitioner's contentions. Nearly all writs of error result in affirmance of the convictions because of the double-barreled rule that the lack of a bill of exceptions restricts the Court's investigation to the common-law record, and that ". . . . the record itself imports absolute verity and can neither be contradicted nor amended except by other matter of record." "In the absence of affirmative statements in the record showing violation of due process, then, the trial court is presumed to have performed its duty properly. During the last year, the Court disposed of allegations that criminal defendants had not been furnished counsel, ${ }^{73}$ had been inadequately represented by counsel, ${ }^{74}$ had not been given an explanation of the consequences of a plea of guilty, ${ }^{75}$ had been sentenced in violation of an agreement made with the State's Attorney for a lighter sentence in exchange for a plea of guilty, ${ }^{76}$ had been convicted on the basis of illegally obtained evidence, ${ }^{77}$ had been coerced and compelled to enter

${ }^{70} 394$ Ill. 380,68 N.E. $2 d 755$ (1946).

7 Ibid.; People v. Conn, 39r Ill. 190, 62 N.E. 2d 806 (I945); People v. Street, 353 Ill. 60, I86 N.E. 534 (1933).

72 People v. Haupris, 396 IIl. 208, 210, 7 I N.E. $2 d$ 68, 69 (1947), cert. den. Haupris v. Illinois, ${ }_{7}$ S. Ct. 1088 (I947); cf. People v. Washington, 396 Ill. 30,7 I N.E. 2 d 9 (1947); People ex rel. Cohen v. Ragen, 392 Ill. 452,64 N.E. $2 d 876$ (1946).

${ }_{73}$ People v. Van Horn, 396 Ill. 496, 72 N.E. 2 d I87 (r947); People v. Creviston, 396 Ill. 78, 7x N.E. 2d 25 (1947); People v. Loftus, 395 Ill. 479, 70 N.E. 2d 573 (1946); People v. McElhaney, 394 Ill. 380,68 N.E. 2d 7I5 (1946).

71 People v. Staryak, 396 Ill. 573, 72 N.E. 2d 8I5 (I947); People v. Christison, 396 Ill. 549, 72 N.E. 2d 185 (r947); People v. Geddes, 396 Ill. 522, 72 N.E. Igr (I947); People ex rel. Thompson v. Nierstheimer, 395 Ill. 572, 7 I N.E. 2 d 343 (I947); People v. Klein, 395 Ill. 449, 70 N.E. 2d 559 (r946); People v. Burnett, 395 Ill. 179, 69 N.E. 2d 856 (1946); People v. Witt, 394 Ill. 405,68 N.E. 2d 73 I (1946).

75 People v. McElhaney, 394 Ill. 380, 68 N.E. 2d 715 (I946).

${ }^{36}$ People v. Burnett, 395 Ill. x79, 69 N.E. 2d 856 (1946).

77 People v. Winston, 395 Ill. 263,69 N.E. 2d 69I (I946). 
a plea of guilty, ${ }^{78}$ and had been rushed into trial $;^{79}$ yet not once was an actual hearing given to determine the truth of the allegations contained in the petitions. The invariablepractice was to declare that since the record failed to sustain the appellants' claims affirmatively, no grounds existed for reversal. Furthermore, the United States Supreme Court last year accepted and applied the Illinois rule which restricts review to those facts disclosed by the common-law record, so that convictions were affirmed in two cases $^{80}$ despite allegations that the petitioners were denied the assistance of counsel in violation of the Fourteenth Amendment. These rulings establish the validity of the Illinois procedure, so that there is very little likelihood that the Illinois Court will alter its practice.

In the few cases in which writs of error resulted in the reversal of convictions, the Court's rulings rested primarily on technical rather than constitutional grounds. Thus petitioners obtained reversals where notice of an amended sentence had been given to the prisoner's former counsel rather than the prisoner himself, ${ }^{8 x}$ where the prisoner's sentence under the Habitual Criminal Act was invalid because his previous sentence had been served in the reformatory instead of the penitentiary, ${ }^{82}$ where the sentence imposed on petitioner was improper ${ }^{83}$ and where a prior conviction had been for larceny of an automobile and not for grand larceny. ${ }^{84}$ Obviously the writ of error is far from a satisfactory method to obtain hearings on the merits where the allegation is the violation of a constitutional right. The Court's adherence to the doctrine of limited review has practically extinguished these writs as a means of securing effective post-conviction hearings.

The remaining state remedy is the motion which has replaced the common-law writ of error coram nobis in Illinois. ${ }^{85}$ This motion brings "before the court rendering the judgment matters of fact not appearing of record, which, if known at the time the judgment was rendered, would have prevented its rendition." 86 Thus the coram nobis proceeding is the only one

${ }^{8}$ People v. Van Horn, 396 III. 496, 72 N.E. 2 d 187 (r947).

${ }^{79}$ People v. Bute, 396 IIl. 588,72 N.E. 2 d 8r3 (1947); People v. Staryak, 396 Ill. 573, 72 N.E. $2 d 8 I_{5}$ (I947).

${ }^{80}$ Foster v. Illinois, 67 S. Ct. $\times 7$ I6, 17 19 (1947); Carter v. Illinois, 329 U.S. I73 (I946).

$8 x$ People v. Wos, 395 THl. $x 72,69$ N.E. $2 d 858$ (1946).

82 People v. Perkins, 395 Xll. 553, 70 N.E. 2d 622 (1946).

${ }_{83}$ People v. Lueckfield, 396 Ill. 520, 72 N.E. 2 d $\times 98$ (1947).

84 People v. Berger, 396 Ill. 97 , 7 I N.E. $2 d 6$ ( $\left(x_{947}\right)$.

85 Ill. Rev. Stat. (I945) c. xro, § 196.

${ }^{86}$ People v. Tuohy, 397 Ill. x9, 24, 72 N.E. 2d 827, 830 (1947). 
in which most prisoners alleging denial of due process of law can obtain an actual hearing on the facts of their allegations. Unfortunately, many prisoners cannot resort to coram nobis because of a five-year limitation period running from the date of conviction; and the limitation has been held constitutional in its application to criminal cases. ${ }^{87}$ Although the statute does provide that the limitation will not apply where the party seeking relief was "under duress, at the time of passing judgment," Court has held that imprisonment after a conviction alleged to be erroneous does not constitute "duress" under the statute. ${ }^{89}$ Hence prisoners whose conviction occurred at least five years ago need not seek coram nobis in order to exhaust their state remedies.90

The full scope of the coram nobis motion is not yet known, since not many prisoners have tried this remedy. But the Court has stated its function as "... to bring to the attention of the court and to obtain relief upon errors of fact, such as death of either party pending the suit, or infancy, where there was no guardian, or coverture, or a valid defense existing in fact but which, without negligence upon the part of the defendant, was not made either through duress, fraud, or excusable mistake of such a character that if known in time would have prevented the rendition and entry of the judgment." for newly discovered evidence, for false testimony at the trial, or for the correction of any matter which has been adjudicated. ${ }^{22}$ In addition, since the motion applies only to facts not known to the court at the time of trial, it may not be used to contradict matters of record. ${ }^{93}$

Two of the coram nobis cases considered in the last year added to the gradual definition of the scope of the remedy. ${ }^{94}$ Greene v. People ${ }^{95}$ held that the coram nobis motion was the appropriate method to review allega-

${ }_{87}$ Ibid.; People v. Rave, 392 Ill. 435, 65 N.E. 2 d 23 (I946).

s8 Ill. Rev. Stat. (r945) c. IIo, § Ig6.

89 People v. Rave, 392 IIl. 435,65 N.E. 2 d 23 (I946).

90 United States ex rel. Rooney v. Ragen, I58 F. $2 d 346$ (C.C.A. 7th, I946), cert. den. 67 S. Ct. r532 (r947).

9r People v. Thon, 374 Ill. 624, 629, 30 N.E. 2d 54, 57 (I940).

92 People v. Tuohy, 397 Ill. I9, 72 N.E. 2d 827 (I947); People v. Gleitsman, 396 Ill. 499, 72 N.E. 2 d 208 (I947); People v. Drysch, 3 II Ill. 342, 143 N.E. I00 (1924).

93 People v. Rave, 392 Ill. 435,65 N.E. $2 d 23$ (I946).

94 The only other coram nobis case decided last term added little to the already known scope of the motion. In People v. Gleitsman, 396 Ill. 499, 72 N.E. 2d 208 (1947), the Court again declared coram nobis motions unavailable to correct false testimony, or to consider new evidence, or to review matters which have been once finally determined.

${ }_{95} 397$ III. 137,73 N.E. 2d 325 (1947). 
tions that a plea of guilty was induced by duress and deceit on the part of the State's prosecuting officials, and that the actions of the latter deprived petitioner of a defense which would have prevented the rendition of the judgment. In People v. Tuohy ${ }^{96}$ the Court reaffirmed the constitutionality of the five-year statutory limitation as it applies to coram nobis proceedings which review criminal convictions, and reiterated the non-availability of coram nobis as a remedy for newly discovered testimony or for alleged perjured testimony. The most significant portion of the opinion, however, dealt with the necessity of affidavits to support allegations in the prisoner's petition. The Court stated that, even upon demurrer, allegations of false testimony by a witness in the trial court would be regarded as conclusions drawn by the pleader and based on hearsay matter, and would therefore not be regarded as true. The Court's holding seems to establish a requirement that the petitioner, in order to invoke the coram nobis remedy, must not only bring his allegations within the limited scope of that remedy, but must support his allegations by affidavits whenever the pleader relies on facts which are not within his personal knowledge.

In its application to criminal defendants seeking review of their convictions, the motion in the nature of a writ of error coram nobis is far superior to either habeas corpus or the ordinary writ of error. The motion should lie to set aside convictions based on coerced confessions, whether or not the petitioners also allege inadequate representation by counsel, and it should also be available to consider allegations of perjury suborned by prosecuting attorneys, since the fraud on the court involved in the latter offense distinguishes it from ordinary false testimony. However, coram nobis motions cannot be used to investigate most charges of lack of counsel, since such lack is obviously a fact known by the trial court; nor can the remedy be employed to allege failure of the trial court to explain the significance of a plea of guilty, since such an allegation contradicts the usual common law record of the trial. Furthermore, the five-year limitation period prevents the use of the coram nobis proceeding by many prisoners. ${ }^{97}$ In short, then, the superiority of the coram nobis motion is purely relative; the inevitable conclusion must be reached that the state of Illinois provides no satisfactory or adequate method for post-conviction hearings, a failure which violates the Fourteenth Amendment.

If the Illinois Supreme Court frankly admitted the virtually complete inadequacy of state remedies, prisoners whose convictions violated their

${ }^{96} 397$ Ill. I9, 72 N.E. 2 d 827 (I947).

97 More than one-third of the criminal opinions handed down by the Court during the I946-47 term involved prisoners who had been convicted over five years ago. 
constitutional rights could seek speedy relief in the federal courts; but such an admission would be embarrassing to the Court. If the Court made a clear, unambiguous statement of what remedies are available and under what circumstances they are appropriate, the present spectacle of petitioners continuously encountering blind alleys in their fruitless search for relief would be halted; ${ }^{98}$ but the Court's failure to make such a declaration, and the use of inconsistent arguments by the Attorney General to avoid the opening of any adequate remedies, seem to disclose a desire to leave the situation in its present vague state if possible. Perhaps most of the petitions are untrue; probably the granting of a full hearing to appellants, with adequate representation by counsel, upon the mere presentation of a verified petition would crowd the court dockets and work hardship on the state courts and State's Attorneys. Neither of these factors, however, in any way justifies the obstacles which stand in the way of all post-conviction hearings. These procedural barriers operate automatically without distinguishing the meritorious petitions from the bad ones.

Solution of the problem will not be an easy task. First, either the legislature or the Supreme Court will have to enlarge the scope of one or more of the presently available remedies, since certain allegations which set up unquestionable violations of the due process clause of the Fourteenth Amendment cannot be reviewed by habeas corpus, writs of error, or coram nobis motions as those procedures now exist in Illinois. The simplest reform would be a retreat from the stand taken in the Swolley case; the Court might broaden the applicability of habeas corpus to include nonjurisdictional problems or, better still, might hold that any conduct which deprives the accused of due process of law destroys the jurisdiction of the trial court to enter judgment.99 Another possibility would be the expansion of the coram nobis motion to include review of facts which were within the knowledge of the trial court at the time of trial, if those facts constitute a denial of due process. If the availability of the motion were made generally known to prisoners, the five-year limitation period would cause less difficulty, so that legislative action might not be necessary. Whichever method might be selected, the limited review available

98 Lee Van Woods (see Woods v. Nierstheimer, 328 U.S. 2 II [r946]) has been in court nine - times without securing a hearing on the merits of his allegations, $:$ nd has now applied for a writ of habeas corpus to the United States District Court for the Northern District of Illinois. John Rooney (see United States ex rel. Rooney v. Ragen, 58 F. 2d 346 [C.C.A. 7th, 1946], cert. den. 67 S. Ct. ${ }^{532}$ [rg47]) required only seven petitions to exhaust his state remedies since his fourteen years' imprisonment eliminated the need to seek relief in coram nobis proceedings.

9" Johnson v. Zerbst, 304 U.S. 458, 468 (r938); see petitioner's brief at I4, Woods v. Nierstheimer, 328 U.S. 2 II (1946). 
on writs of error would lose its significance. If Illinois state courts furnished effective machinery for post-conviction hearings, the necessity of seeking writs of error as a prerequisite to relief in the federal courts would vanish.

Once a method has been provided for hearing all claims of violation of constitutional rights in criminal proceedings, means must be established to prevent the glutting of the courts with fabricated or insufficient petitions. One possibility would be to refer all petitions to the public defender, or other counsel in a capacity as friend of the court. ${ }^{100}$ This requirement would be useful not only in withdrawing a heavy burden from the courts, but also in aiding the petitioners to stay out of procedural pitfalls. ${ }^{\text {Ior }}$ The friend of the court, assuming all the allegations to be true and interpreting the petition liberally as required by the United States Supreme Court, ${ }^{102}$ should advise the court of his opinion as to the sufficiency of the petition. If the court then finds that the petition fails to state a cause of action or that the wrong remedy has been chosen, it should grant the state's motion to dismiss the petition, but it should be required to state the grounds upon which dismissal is based.

If, on the other hand, the allegations establish a prima facie valid case for relief, the courts might adopt, in modified form, the requirement set up in the Tuohy case: appellant should be required to file supporting affdavits sworn to by any witness whose testimony would be required to establish petitioner's claim. After the state had filed answering affidavits, the court might determine whether the affidavits would justify the giving of a full hearing to petitioner. Such a selective weeding-out process, which

${ }_{100}$ Unfortunately, mere representation of the prisoner by appointed counsel is not enough to insure that the Court will give the petition adequate consideration. Thus, petitioner Van Woods sought coram nobis in the Criminal Court of Cook County in July, r945, alleging inadequate representation by counsel and use of a coerced confession at his trial. The allegations were later held to establish a clear denial of due process in Woods v. Nierstheimer, 328 U.S. 2 II (I946). The petitioner was represented by the chairman of the Chicago Bar Association Committee for Defense of Prisoners, yet the "hearing" consisted only of the following:

Counsel: He is asking a writ of coram nobis. He was not given advice as to the correct plea and all of that, all of which was unknown to him at the time. He sets up in the petition he was under the influence of narcotics.

The Court: Leave to file the petition for coram nobis without costs. Petition dismissed.

sor The Illinois Supreme Court has ruled that where a prisoner has been sentenced for an erroneous term, he must be resentenced and serve his new sentence without credit for time served under the erroneous term, unless the trial court chooses to diminish the new sentence accordingly. Thus the prisoner seeking review may only succeed in obtaining a resentence which, added to the time already served, is longer than the original erroneous sentence. This unjust rule was applied last term in People v. Heard, 396 IIl. 215, 7I N.E. 2d 321 (x947); People v. Judd, 396 Ill. 2II, 7I N.E. 2d 29 (I947); and People v. Starks, 395 Ill. 567, 7I N.E. 2d 23 (I947). Such results might have been avoided had prisoners been advised by counsel.

s02 Hawk v. Olson, 326 U.S. 27I, 276 (I945); Tomkins v. Missouri, 323 U.S. 485, 487 (I945). 
is similar to one approved by the United States Supreme Court, ${ }^{103}$ should certainly fulfill the requirements of due process.

Whatever plan is finally adopted, there can be no doubt that now is the time for the Court to take some affirmative action to remedy a very unhealthy situation. For the most part, the Court's decisions during the I946-47 terms only raised higher the procedural barrier behind which the Court shelters itself from the spectacle of criminal appellants vainly seeking post-conviction hearings. Until the problem is met by providing means for such hearings, the change in Illinois prison rules which allowed petitions to be sent out of the penitentiary must be regarded, at best, as a mixed blessing. ${ }^{\text {ro4 }}$

\section{PUBLIC IAW}

Approximately 23 per cent of the cases decided during the last year involved questions of public law. ${ }^{\text {ros }}$ The more important can be classified in a few categories: constitutional law, taxation, and law of local government bodies. Of these the most widely debated were three constitutional law cases. People ex rel. McCollum v. Board of Education of School District No. $7 \mathrm{I}^{\mathrm{ro6}}$ involved the Champaign Board of Education's action permitting church-financed religious instruction of public-school children. Instruction was given during school hours and in school buildings, upon the written request of the parents of the children concerned. The plaintiff, a taxpayer and parent of a child attending a district public school, sought mandamus to compel discontinuance of such instruction on the ground that it violated Article II, Section 3 of the Illinois Constitution. ${ }^{107}$ The trial court denied the writ, and the Supreme Court affirmed the denial.

The Court held that no prohibition of the free exercise of religion was involved in the program since participation was voluntary. According to the Court, the stigma attached to non-participation was not compulsion..$^{08}$

${ }^{303}$ Hysler v. Florida, 3I5 U.S. 4II, 4I5-I7 (I942).

${ }^{104}$ In United States ex rel. Bongiorno v. Ragen, 54 F. Supp. 973, 975 (Ill. , I944), aff'd I46 F. 2 d 349 (C.C.A. 7th, 1944), cert. den. Bongiorno v. Ragen, 325 U.S. 865 (I945), petitioner secured a hearing on the merits of his claim with only one petition, since the complete absence of available remedies in Illinois courts gave him access to the federal courts. For prisoners who could reach the federal district court by any method, relief was thus far speedier than under the present "more liberal" rule.

ros See Table 5, at $\mathrm{I} 7 \mathrm{I}$ infra.

${ }^{106} 396$ Ill. I4, 7I N.E. 2d x6I (1947), cert. granted 67 S. Ct. 1524 (1947).

so7 "The free exercise and enjoyment of religious profession and worship, without discrimination, shall forever be guaranteed, and no person shall be denied any civil or political right, privilege, or capacity, on account of his religious opinions." Ill. Const. Art. II, § 3.

${ }^{108}$ People ex rel. Latimer v. Board of Education of Chicago, 394 Ill. 228, 68 N.E. 2d 305 (1946) sustained the constitutionality of an arrangement whereby children were excused from school to attend religious education classes. 
People ex rel. Ring v. Board of Education, ${ }^{\text {xo9 }}$ invalidating a daily classroom program involving Bible-reading and prayer, was distinguished on the basis that participation in that program was required of all pupils. And because the expense of the program to the taxpayers was found to be limited to wear and tear on furniture and floors, it was held to fall within the de minimis doctrine, and, therefore, not to violate the Illinois constitutional provisions guaranteeing free exercise of religion and prohibiting payment of-public funds for religious purposes. ${ }^{\text {ro }}$

There is a division of opinion in state courts on the constitutionality of Bible-reading programs similar to the one struck down in the Ring case. ${ }^{\text {IxI }}$ The difficulties surrounding this subject are abundantly illustrated in the recent school-bus case before the United States Supreme Court. ${ }^{\text {Ix2 }}$ But these difficulties were largely ignored by the Illinois Court in the $\mathrm{McCol}$ lum case. For example, there was no investigation of whether participation is really voluntary in a program supported by both the prestige of the state, operating through the public school, and the social pressure of attendance by every child but the plaintiff's. Nor was there any inquiry as to whether the de minimis maxim is properly applicable to an absolute probibition involving the delicate church-state relationship.

Although of less general legal interest, two cases this term involving veterans' rights immediately concerned the layman. The constitutionality of the Illinois veterans' bonus was upheld in Routt v. Barrett, , $\times 3^{3}$ a taxpayers' suit to enjoin state officials from disbursing public moneys to pay the expenses of submitting the bonus bond issue to the electorate. By the time the Routt case was decided, the bond issue had already been approved by the voters. The Court did hear the constitutional issues, however, after allowing the complaint to be amended.

This case and Bilek v. Chicago ${ }^{\mathrm{Ir} 4}$ present good examples of the present expensive, time-consuming procedure for testing the constitutionality of

${ }^{209} 245$ III. 334, 92 N.E. 25I (r910).

Iro "No person shall be required to attend or support any ministry or place of worship against his consent, nor shall any preference be given by law to any religious denomination or mode of worship." Ill. Const. Art. II, § 3. Neither the general assembly nor any.... school district .... shall ever make any appropriation or pay from any public fund whatever, anything in aid of any church or sectarian purpose, or to help support or sustain any school .... controlled by any church or sectarian denomination whatever; nor shall any grant or donation .... . ever be made by ..... any such public corporation, to any church, or for any sectarian purpose." IIll. Const. Art. VIII, §3.

IIr See cases cited in 5 A.L.R. 866 (I920) supplemented in I4I A.L.R. II44 (I942).

Ixz Everson v. Board of Education, 330 U.S. I (I947).

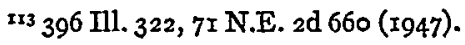

${ }^{\pi \times 4} 396$ Ill. 445,7 I N.E. 2 d 789 ( ${ }^{2} 947$ ), holding invalid a superhighway bond issue. 
proposed bond issues requiring approval by the people. By the time a case is heard in the Supreme Court, the proposal will, in many cases, already have been approved by the voters. If the issue should then be held invalid, the time and expense of publication and submission to the voters will have been wasted. Furthermore, if the subject is one on which rapid action is desirable, the time already lost, plus the time required to resubmit the question in a future general election in a form meeting constitutional requirements, may prove an insuperable, obstacle to adequate timely legislation.

The constitutionality of other veterans' legislation was involved in People ex rel. Jendrick v. Allman. ${ }^{\mathrm{Irs}}$ A I945 amendment to the City Civil Service Act contained a provision exempting war veterans from civil service discharge for misstatement of age. ${ }^{\mathrm{x} 6}$ Twenty-seven years is the maximum eligible age for police examination applicants. The 1945 amendment seems to have been designed to circumvent this age requirement as far as veterans were concerned. The petitioner was a World War I veteran discharged from a position as patrolman in Chicago for misstating his age on his application for civil service examination. He brought a mandamus proceeding to compel the police commissioner to reinstate him in accordance with the exemption stated in the act. The Court held the provision in question unconstitutional in that it discriminated against persons without basing that discrimination on a reasonable distinction in circumstances. In Igr4 the Court had upheld veterans' preference in Civil Service positions. ${ }^{117}$ However, according to another line of precedent there must be some substantial difference between classes to justify preference, and such difference must relate to the purpose of the act. ${ }^{\mathrm{Ir} 8}$ It seems clear that a veteran who misstates his age is not more desirable as a public servant than any other person making misstatements. The maximum age of twenty-seven apparently was set to promote efficiency, probably based on length of potential service and on physical capabilities. Exemption of veterans from this requirement, therefore, cannot be said to promote efficiency on the police force. There is no inconsistency between allowing a certain amount of public appreciation for war service and drawing the line short of unreasonable and inefficient privileges.

Of far-reaching importance to the preservation of Mllinois land are cases

${ }^{215} 396$ Tll. 35, 7x N.E. 2 d 44 (1947).

${ }^{216}$ Ill. Rev. Stat. (1945) c. $24 \frac{1}{2}, 85 \mathrm{r}$.

a7 People ex rel. Sellers v. Brady, 262 Ill. 578, y05 N.E. I (19r4).

us People v. Linde, 34 I Ill. 269, I73 N.E. 36 I (1930); Wintersteen v. National Cooperage \& Woodenware Co., 361 Ill. 95 , 197 N.E. 578 (1935). 
involving the constitutionality of legislative attempts to compel individual property owners to use their land in such a way as to conserve the state's resources. One such statute was struck down during the r $946-47$ session in Northern Illinois Coal Corp. v. Medill..$^{\mathrm{xy}}$ Suit was brought to enjoin the Director of Mines and Minerals from enforcing provisions of an act requiring operators engaged in "open cut" or "strip" coal mining to restore the land to approximately its original contour..$^{\mathrm{x20}}$ The Court held that the statute was not a true public health or conservation measure and hence was unconstitutional as an invalid exercise of the police power.

The Court's reason for holding that the statute was not a public health measure, tending to eliminate breeding places for bacteria and mosquitoes, was that the statute required restoration of the original contour of the land. Thus, argued the Court, if the land originally contained pools or swamps, such features presumably would also have to be restored. The Court cited cases holding that property rights may not be invaded under the guise of protection of public health when that is not the purpose of the regulation. ${ }^{\mathrm{x} x}$ It found that the testimony of two witnesses that the water in the pools in the open cuts would sustain life and breed bacteria and mosquitoes, like any other stagnant water, was insufficient evidence to show that the public health was endangered. The Court also indicated that even if the regulation were a valid exercise of police power, it would be invalid in this case as an unreasonable discrimination against coal "strip" mine operators, as compared, for example, with quarry owners. There was no discussion of the prevalence of the coal "strip" mining wastes as compared with quarry wastes, nor was there any inquiry into the practical difficulties of restoring the original contour of rock quarries. Since in Illinois, coal "strip" mining creates the major problem, and since the material for filling is on hand, the legislature seems to have made no unreasonable distinctions between classes. And reasonable distinctions between classes can be made in the exercise of the police power. In this case, since the practical problem is almost synonymous with coal "strip" mining, the distinction would appear quite reasonable.

A statute permitting the City of Chicago to issue slum-clearance bonds and levy taxes to pay for them ${ }^{\mathrm{r2}}$ was upheld in a second land case, People ex rel. Tuohy v. Chicago. ${ }^{\mathrm{I23}}$ Here, a quo warranto proceeding attacked the

${ }^{219} 397$ Ill. 98,72 N.E. $2 d 844$ (1947).

${ }^{220}$ Ill. Rev. Stat. (1945) c. $93, \$ \S 162-80$.

${ }^{22 x}$ Bailey v. People, rgo Inl. 28, 60 N.E. 98 (Igor); People v. Carolene Products Co., 345 III. I66, I77 N.E. 698 (I93I).

InIll. Rev. Stat. (rg45) c. 24,88 23-ro3.I. ${ }^{223} 394$ Ill. 477, 68 N.E. 2 d 76I (ร946). 
statute on the theory that it attempted to empower a municipality to acquire private property for other than public purposes. The Court deemed rehabilitation of slum areas a public use within the meaning of the constitution even though the leasing or sale of such areas to private persons was contemplated. The decision, a logical extension of Zurn v. Chicago, ${ }^{\mathbf{1 2 4}}$ paves the way for extensive improvements in housing conditions in Illinois, both through direct state action and through state grants of power to municipalities.

That tax exemption is available for municipal airports is indicated by People ex rel. Lawless v. Quincy. ${ }^{125}$ Local taxing bodies sought a judgment and order of sale for delinquent taxes on an airport owned by the City of Quincy but situated several miles outside the city. The city alleged that the airport was tax exempt under the Revenue Act of $1939 .{ }^{126} \mathrm{~A}$ majority of the Court held that the airport was used for public purposes under Subsection 9 . The parties, however, had argued the case solely under Subsection 6. Two judges, specially concurring, pointed out that, under the ejusdem generis rule of statutory interpretation, Subsection 9 should be applied only to kinds of things similar to those enumerated, namely market houses and public squares. They said, however, that the airport would be tax exempt under Subsection 6, since they believed that it was used exclusively for municipal purposes. Both the majority and the concurring judges avoided the problem of defining an "exclusive municipal purpose," the former by basing the decision on Subsection 9 and the latter by merely stating that an airport was used for such a purpose. It may be inferred that since the Court agreed on tax exemption for two different reasons it is willing to use the act to provide a broad base for municipal tax exemption. ${ }^{.27}$

Situations may arise, however, where "public purposes" and "municipal purposes" will have to be defined more precisely. Such a situation may be presented by problems involving metropolitan areas. If, for example, Chicago were to operate a metropolitan water supply system, with some

${ }^{224} 389$ Ill. 114,59 N.E. 2 d 18 (I945). This case held that a law authorizing a private corporation to take private property for the redevelopment of slum and blighted areas authorized a taking for a public use.

${ }^{225} 395$ III. I90, 69 N.E. $2 \mathrm{~d} 892$ (1946).

${ }^{226}$ Ill. Rev. Stat. (1945) c. 120, $\$ 500$. The act provides for tax exemption in part as follows:

"(6) .... all property owned by any city or village outside of the corporate limits of the same if used exclusively for municipal purposes. ...."

"(9) All market houses, public squares and other public grounds owned by a municipal corporation and used exclusively for public purposes."

I27 Would not this case indicate, for example, that housing developments such as involved in People ex rel. Tuohy v. Chicago, 394 Ill. 477,68 N.E. 2d 76r (I046), are tax exempt? 
of the necessary property located outside the city, the "public purposes" clause would almost surely not apply, since the use would be limited to inhabitants of the city. ${ }^{\mathbf{I 2}}$ Sale of water to other communities would arguably not be a municipal purpose, and at least a part of such a project ${ }^{229}$ might be subject to taxation. Thus a strict or liberal interpretation of "exclusively municipal purposes" may have considerable influence on future planning of metropolitan projects.

Another group of cases which received some public attention were those involving the law of state and local government bodies. One of the most difficult problems facing the Court in this group of cases stems from appeals seeking relief from rulings of government agencies. The Court recently has shown some tendency to refuse recognition of the validity of legislative and administrative determinations and to substitute its own judgment for that of a city council or board equipped to handle the technical issues. This tendency is illustrated in 2700 Irving Park Building Corp. v. Chicago. ${ }^{\times 30}$ The plaintiff in that case had purchased, in I94I, a fiftythree-acre tract of land for industrial purposes. The land bordering on the tract had been and was both industrial and commercial. Most of the surrounding area, however, was residential. Before construction was started by the plaintiff, the Chicago City Council passed a zoning amendment, ${ }^{\text {,3x }}$ which provided for the rezoning of a portion of the tract for apartment usage. Subsequently a spot zoning amendment ${ }^{\mathrm{T} 32}$ rezoned the entire tract for apartment usage. The plaintiff brought suit to set aside the zoning legislation as a taking of property without due process of law. On appeal, the Supreme Court affirmed the lower court's decision, holding the ordinances void with respect to the plaintiff's property.

The Court carefully pointed out that in determining the validity of rezoning ordinances, its inquiry is limited to whether the City Council had authority to pass the ordinance and whether the ordinance has a reasonable relation to the public health, safety, and welfare, or is unreasonable or arbitrary. ${ }^{.33}$ Despite this dictum, the Court reasoned that since the "high-

${ }^{228}$ City of Mattoon v. Graham, 386 IIl. r8o, 53 N.E. 2d 955 (r944).

r29 People ex rel. Lawless v. City of Quincy, 395 Ill. xgo, 200, 69 N.E. 2d 892, 897 (1947).

${ }^{\mathrm{x} 30} 395$ Ill. $\mathrm{x} 38,69$ N.E. 2d 827 (r946), noted in 14 Univ. Chi. L. Rev. 718 (r947); cf. also Illinois Central R. Co. v. Illinois Commerce Commission, 395 Ill. 303 , 70 N.E. $2 \mathrm{~d} 64$ (I946).

${ }^{x 3 z}$ Comprehensive Amendment to the Chicago Zoning Ordinance Chicago Rev. Code (1946) § 194A.

${ }_{332}$ Chicago Rev. Code ( 9946$) \S 194 \mathrm{~A}-\mathrm{r}$.

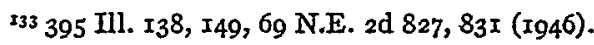


est and best use" ${ }^{\prime 34}$ of the fifty-three acre tract was industrial, ${ }^{135}$ and inasmuch as the trend in the immediate neighborhood had been industrial for two decades, the plaintiff should be allowed to use his property for manufacturing purposes. By setting up a standard for zoning legislation which did not take into consideration the comprehensive problems of city planning, the Court not only usurped the function of the City Council in determining the best use of the land, but introduced serious obstacles in the way of a much needed comprehensive rezoning plan for the City of Chicago. Similar revisions of zoning ordinances by the Court have occurred before in Illinois. ${ }^{136}$

But the Court has in some instances quite vigorously upheld the administrative acts of zoning commissions. ${ }^{\mathrm{x} 7}$ In DeBartolo v. Oak Park, ${ }^{, 38}$ decided during the past term, the Court in upholding the enforcement of a zoning ordinance of the Village of Oak Park said, "A zoning ordinance is presumed to be valid. The burden is upon one assailing such an ordinance to overcome this presumption. Where a general zoning ordinance is passed, those who buy property in zoned districts have the right to rely upon the rule of law that the classification made in the ordinance will not be changed unless the change will be required for the public good." ${ }^{39}$ In that case, a petition to convert a dwelling into a two-family apartment building in a district zoned for single family uses had been denied. The plaintiff contended that the zoning ordinance was unreasonable as applied to her property because of the presence of multiple dwellings on the same and adjoining blocks, ${ }^{\mathrm{I} 40}$ and because nearby property was zoned for commercial use. The contrast between the judicial technique used in this case and that used in the Irving Park case is notable. In the DeBartolo proceeding, the Court emphasized the presumptive validity of zoning ordi-

\footnotetext{
${ }^{234}$ For a discussion of the "best use" test, see $\mathrm{r}_{4}$ Univ. Chi. I. Rev. 7 I8 (I947), noting the instant case.

${ }_{135}$ Two expert witnesses testified to the effect that the best use of the land was industrial, while two other experts maintained that it was residential.

${ }^{236}$ Anderman v. Chicago, 379 Ill. 236, 40 N.E. 2d 5 I (1942); La Grange v. Leitch, 377 Ill. 99, 35 N.E. $2 d 346$ (194I); Harmon v. Peoria, 373 Ill. 594, 27 N.E. $2 d 525$ (1940); Forbes v. Hubbard, 348 III. I66, I80 N.E. 767 (1932).

${ }^{232}$ Zadworny v. Chicago, 380 IIl. 470, 44 N.E. 2 d 426 (I942); Minkus v. Pond, 326 Ill. 467 , 158 N.E. I2I (I927); Aurora v. Burns, 3 Ig IIl. 84 , I49 N.E. 784 (I925). The cases are in accord with the approach of the United States Supreme Court in Euclid v. Ambler Realty Co., 272 U.S. 365 (rg26) and Zahn v. Board of Public Works, 274 U.S. 325 (1927).

${ }^{238} 396$ Ill. 404, 7 I N.E. 2d 693 (I947).

r39 Ibid., at 4 Io and 696 .

${ }^{1} 4^{\circ}$ Evidence showed that these multiple dwellings had been constructed prior to the passage of the ordinance under attack by plaintiff.
} 
nances, which can be rebutted only if the opponent of the ordinance can show that his constitutional property rights have been invaded, while in the Irving Park opinion, primary stress was laid upon the freedom of property owners to use their land as they desire, limited only by a reasonable exertion of the police power. The same principles were apparently asserted in each case. The manner in which the Court laid emphasis on one or the other of two opposing concepts, however, determined the decisions, while giving the impression that no difficult problem existed.

Other local government problems before the Court involved controversies arising from agreements between municipalities and private individuals. The most important of these cases was Yellow Cab Company v. Chicago, $^{\mathrm{IAx}}$ involving the contract rights of taxicab licensees. In I934, the Chicago City Council had passed an ordinance providing for the issuance of taxicab licenses. Of 4,Ioo licenses issued, the plaintiff Yellow and Checker Cab companies received approximately 3,600. The ordinance provided that the licenses issued were to be effective until I 940 unless revoked sooner, that no further licenses were to be issued without a determination of public necessity at a public hearing, and that if a licensee failed to operate his cab for some reason within his control, his license could be revoked.

In $x_{937}$, the business recession made it necessary to reduce the number of taxicabs on the streets. An ordinance was therefore passed providing for voluntary surrender of taxicab licenses. In return for the surrender of his license, a licensee was to have a thirty-day option to take up any new license issued when the city determined that more taxicabs were needed. Almost all of the licenses surrendered were given up by the plaintiffs. The ordinance also extended the remaining licenses until I945, when another ordinance was enacted renewing them until I950.

As a result of their inability to replace automobiles and parts during the war, the plaintiff companies were unable to operate a number of cabs equal to the number of licenses held. Increased public demand for better transportation stimulated the City Council to pass an ordinance in 1946 providing for the issuance of 250 "permits" for the operation of taxicabs. These "permits" were to be distributed equally throughout the city, with preference given to ex-servicemen. At the same time, the Public Vehicle License Commissioner took steps to revoke the licenses of plaintiffs, unless the latter could put idle cabs back into operation within five days. The present action was brought to enjoin such revocation of licenses and also to restrain the issuance of "permits."

${ }^{x 4 x} 396$ Ill. 388,7 I N.E. 2d 652 (I947); cf. Branigar v. Village of Riverdale, 396 Ill. 534,72 N.E. $2 \mathrm{~d} 201$ (I947). 


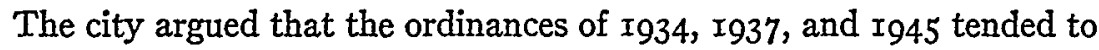
create a monopoly for the plaintiffs and were therefore void. The Court, in ruling for the plaintiffs, held, in accord with Illinois precedents, ${ }^{\mathrm{I} 4 \mathrm{Ia}}$ that the ordinances in question were irrevocable contracts between the city and the licensees and that therefore the commissioner could not revoke the licenses. The ordinance authorizing the issuance of permits was declared invalid since it did not attempt to bring the new cabs and drivers under the same regulations as the other taxicabs in the city, nor did it provide for a termination of those "permits" when the original taxicab licensees would be able to furnish the service which the public required. It is apparent under the latter holding that the immediate need for more taxicab service in the city could have been met by appropriate amendment to the "permit" ordinance. But the question of monopoly would still be present, since the permit-holders would have to leave the field once the plaintiffs could meet the physical demands for service. The Court in rejecting the city's contention that the ordinances tended to create a monopoly, relied on Capitol Taxicab Company v. Cermak, ${ }^{\mathrm{x}}{ }^{2}$ involving a Chicago ordinance similar to that passed in I934. There, it was held that since the city had reserved the right to issue new licenses after public hearings and a showing of public necessity without obtaining consent from previous licensees, no monopoly was created.

Theoretically this right remained unchanged after the contract ordinance of 1937, but it is not so clear that the provision had any practical value after the grant of an option to the plaintiffs. The city would have had to issue almost a thousand licenses to this group, increasing the city's cabs by more than a third, before it could begin issuing licenses to potential competitors. It would also require several hundred more licenses before the newcomers could become numerous enough to offer effective competition. In view of the 1937 depression experience, illustrating the dangers to public safety of too large a number of competing cabs, such action by the city seems unlikely. The Court recognized these practical results of the passage of the I937 "option" ordinance, but it ruled that no monopoly was created, since the ordinance was of general application and within the power of the city to enact.

A recent decision of the United States Supreme Court has recognized the monopolistic character of the Chicago taxicab situation, while ruling

${ }_{\text {x41 }}$ Peoria Railway Co. v. Peoria Railway Terminal Co., 252 Ill. 73, 90 N.E. 689 (I9Ir); People v. Blocki, 203 Ill. 303,67 N.E. 809 (rgo3); Chicago v. Oak Park Elevated R. Co., 250 III. 486,95 N.E. 456 (IgII).

$x 4260$ F. 2d 608 (D.C. Ill., x932). 
that no cause of action was stated under the Sherman Act, since local taxicab service did not involve interstate commerce. ${ }^{x 43}$

Also within the category of Public Law is a group of taxation cases. Although none of these cases is in itself of great importance, together they are indicative of the Court's approach to difficult problems of statutory construction. Most of the Court's tax work is limited to considering narrow technical objections to the methods of administering the archaic Illinois general property levy. ${ }^{x 4}$ Numerous cases strike down exercises of the taxing power not meticulously conforming to the statutes. In a few cases, however, where the interpretation of ambiguous statutory provisions raises questions substantially affecting taxation procedure and revenue returns, the Court diligently inquired into and furthered the legislative purpose.

An example of a case in which the Court's decision hinged on a trivial defect is Saline Branch Drainage District v. Urbana-Champaign Sanitary District, ${ }^{\text {15 }}$ in which it was held that a judgment confirming a special assessment against the "U. \& C. Sanitary Dist." violated the constitutional provision that judicial proceedings be in the English language because the quoted phrase is not "intelligible to a person understanding the English language without other knowledge." People ex rel. Anderson v. Chicago \& N.W.R. $\mathrm{Co}^{{ }^{14^{6}}}$ was a similar case, involving the question of compliance by a city council with the requirement of a recordation of the vote of each council member by yeas and nays. The record showed: "Voting Aye 5. Nay none. Carried." In insisting that the vote of each member be recorded by name, the Court stated that it could not "indulge the speculation .... that the five members of the council noted as present were the five voting aye"! The council consisted of only five members.

In People ex rel. McWard v. Wabash $R$. Co. ${ }^{147}$ the Court held that a certified copy of the tax levy ordinance and not the original copy must be filed with the county clerk. If the document upon which the county clerk

${ }^{243}$ United States v. Yellow Cab Co., 67 S. Ct. 1560 (1947).

${ } 44$ Objections are usually raised by. railroads which have enough at stake as large taxpayers to justify the costs of the suits. People ex rel. Hargrave v. Baltimore \& Ohio R. Co., 394 Ill. 47I, 68 N.E. 2d 768 (1946); People ex rel. McWard v. Wabash R. Co., 395 Ill. 243, 70 N.E. 2 d 36 (1946); People ex rel. Goodman v. Wabash R. Co., 395 Ill. 520, 70 N.E. 2d 718 (I947); People ex rel. Schlaeger v. Riche, 396 Ill. 85, 7r N.E. 2d 333 (r947); People ex rel. Wilson v. Illinois Central R. Co., 396 Ill. 5 I0, 72 N.E. 2d 330 (1947); People ex rel.Prindablo v. New York Central R. Co., 397 Ill. 50, 72 N.E. 2d 821 (1947).

${ }^{345} 395$ Ill. 26,69 N.E. 2 d 25 I (1947).

${ }^{146} 396$ Ill. 466,7 I N.E. 2 d 7 OI (I947).

${ }^{247} 395$ Ill. 243 , 7o N.E. 2 d 36 (1946) 
bases his authority for extending the tax purports on its face to be the original ordinance and not a copy thereof, the levy is void..$^{18}$ Even though the document is in fact a copy, it cannot be amended by adding a certification to show that it is a certified copy and not the original. ${ }^{\mathbf{3} 9}$ But if the document filed appears on its face to be a copy even though not certified, it may subsequently be amended by adding the necessary certification to support the tax. ${ }^{150}$ The result is that in the statutory phrase "certified copy" the Court puts emphasis upon "copy" and not upon "certified." This emphasis only complicates tax procedure without adding to the taxpayer's protection, for it is clear that the fact of certification rather than the fact of copying is what protects him. The filing of the original ordinance actually gives the taxpayer greater protection than filing a certified correct copy, since the sole purpose of certification is to insure that the copy is a true one.

This decision, however, is in conformity with a line of Illinois precedents ${ }^{I S x}$ all based upon one case. ${ }^{152}$ But that case is distinguishable because it involved the filing of an appropriation ordinance instead of a levy ordinance. Thus, a closer examination of the original precedent might have avoided invalidating the tax on a purposeless technical ground.

On the other hand, where the issue was the interpretation of ambiguous statutory provisions, the Court in two cases found the interpretation which most reasonably fulfilled the legislative objectives. ${ }^{x 3}$ The more important was Anderson v. Park Ridge $e^{254}$ which required a construction of section I62(a) of the Revenue Act. ${ }^{\mathrm{Is5}}$ This section, setting the maximum and minimum rates for the extension of 1946 taxes in all taxing districts in the state with a population of less than 500,000, was part of a comprehensive legislative plan to cure the flagrant lack of uniformity caused by the longestablished practice of locally assessing property at less than its full value.

${ }^{348}$ C., I., \& W. R. Co. v. People, $2 I_{3}$ Ill. I97, 72 N.E. 774 (I904); Village of Russellville v. Purdy, 206 Ill. I42, 68 N.E. 1085 (1903).

149 People ex rel. Wangelin v. Picairn, 37 I Ill. 6I6, 2I N.E. 2d 753 (1939); People ex rel. Riche v. C. \& E. I. R. Co., 3 I5 Ill. 424, I46 N.E. 499 (I925); People ex rel. Carr v. Chicago \& N. W. R. Co., 3ז2 Ill. 58, r43 N.E. 460 (r924); People ex rel. Daugherty v. Wabash R. Co., 256 IIl. 329 , 100 N.E. 26 I (I9I2).

${ }^{x 50}$ People v. Patten, 287 Ill. 392, I22 N.E. 47 I (rgrg); People v. Kankakee and Seneca R. Co., 256 Ill. 4r9, 100 N.E. 254 (19I2).

25: Cases cited notes $148-50$ supra.

Isz Village of Russellville v. Purdy, 206 Ill. 142, 68 N.E. I085 (I903).

${ }^{x s 3}$ People ex rel. Hutchcraft v. Louisville \& Nashville R. Co., 396 IIl. 502, 72 N.E. $2 d 194$ (I947); Anderson v. Park Ridge, 396 Ill. 235, 72 N.E. 2 d 2 ro (1947).

${ }^{254} 396$ Ill. 235,72 N.E. 2d $2 \times 0$ (r947). $\quad 355$ Ill. Rev. Stat. (I945) C. 120,8643 (8). 
The legislation required all counties to assess at Ioo per cent and, then, in order to prevent substantial increases in tax collections, reduced maximum tax rates 50 per cent. The combination of an increase in assessments to roo per cent and a reduction in rates to 50 per cent left those counties which had previously assessed at $5 \circ$ per cent with the same taxing power, those which had previously assessed at less than 50 per cent with more taxing power, and those which had previously assessed at more than 50 per cent with less taxing power.

Section $I 6_{2}(\mathrm{a})$ attempted to remove this variation by fixing in paragraph I a minimum amount extendable and by limiting in paragraph 2 the tax rate to 15 per cent more than a formula maximum, "provided that in no one year during aforementioned five-year period shall the tax extension be increased to exceed 5 per cent of the maximum extendable in x942." A literal reading of the proviso appears to indicate that the amount of revenue to be raised under paragraph 2 could not exceed by more than 5 per cent the maximum amount that could have been raised in 1942. The taxpayer urged this interpretation, but the city argued that the proviso only limited paragraph 2. The Court, however, more reasonably interpreted the proviso to mean that the $5_{5}$ per cent increase in rates stipulated in paragraph 2 was limited so that the increase in revenue in any one year which could be raised by the increase over the formula rate could not exceed 5 per cent of the maximum tax extendable in I942. This decision permits a gradual increase in tax extensions during the five-year period, whereas the interpretations of either the city or the taxpayer would have permitted an abrupt increase in collections at the end of the period.

\section{PRIVATE LAW}

As has already been indicated, a relatively small percentage of the litigation reaching the Illinois Supreme Court last term was between private parties. Moreover, more than half of the cases between private parties involved property; fewer than 2 per cent were concerned with commercial relations, and fewer than 4 per cent with torts. ${ }^{x 56}$ None of the tort cases ${ }^{157}$ or of the commercial cases ${ }^{158}$ made any important changes in Illinois law. Nor did any of them indicate a significant trend in the Court's approach

${ }^{156}$ See Table 5, at I7I infra.

${ }^{157}$ Schneiderman v. Interstate Transit Lines, Inc., 394 Ill. 569, 69 N.E. 2d 293 (I946); Zitnik v. Burik, 395 Ill. 182,69 N.E. $2 d 888$ (I946); Miller v. Miller, 395 Ill. 273,69 N.E. 2 d 878 (I946); Westinghouse Electric Elevator Co. v. LaSalle Monroe Building Corp., 395 Ill. 429,70 N.E. 2 d 604 (1946).

${ }_{258}$ Mills v. Susanka, 394 Ill. 439, 68 N.E. 2d 904 (I946); Dean v. Kellogg, 394 Ill. 495, 68 N.E. $2 d 898$ (I946); Henrys v. Raboin, 395 Ill. Ir8, 69 N.E. 2d 49 (1946); Doggett v. North American Life Ins. Co., 396 Ill. 348, 7 I N.E. 2d 690 (1947). 
to these kinds of problems. Similarly, the trust cases ${ }^{159}$ during the last year cannot be said to have effected any change in Illinois trust law. In most of them, the Court was required to sift conflicting testimony and then apply well-known principles to the determined facts.

The significant cases in this section fall into four categories: real property, wills and probate, family relations and divorce, and labor. All of the labor cases last year involved claims under the Workmen's Compensation and Unemployment Compensation Acts. Although, strictly speaking, they are not litigations between private parties, nevertheless, the issues in these cases always involve a conflict between employee and employer over their respective rights under state labor statutes.

Because of the direct review of right in freehold cases the Supreme Court's attention in real property litigation is often preempted by trivial issues complicated only in their facts. The most significant and disturbing of the few important decisions was Wloczewski v. Kozlowski. ${ }^{160}$ There, the prospective vendors employed a real estate dealer to find a purchaser for their property. Since the plaintiff, the would-be purchaser, preferred to remain anonymous, the real estate dealer suggested that a clerk act as agent and that the purchaser remain an undisclosed principal. The purchaser orally consented to this arrangement, and a contract was drawn by the real estate dealer and signed by the vendors and the agent. When the vendors repudiated the contract, the agent, later joined by the purchaser as real party in interest, sued for specific performance. The Court denied relief, assigning as one reason the real estate dealer's duplicity in acting for both vendor and purchaser without fully disclosing the details of his dual agency. Thus confined to the narrow facts of the case, the decision is in line with the authorities. ${ }^{\mathrm{x} x}$ The Court, however, emphasized two other grounds, and in so doing increased the confusion in Illinois law relating to mutuality and undisclosed principals.

Applying what it called a "settled principle of equity," the Court stated that since the vendor would have been barred by the statute of frauds from enforcing the oral contract between the undisclosed principal and

זs9 Belleson v. Ganas, 394 Ill. 557, 69 N.E. 2d 32I (I946); Harrison v. Kamp, 395 Ill. II, 69 N.E. 2d 26I (r946); Dyer v. Paddock, 395 Ill. 288, 70 N.E. 2d 49 (1946); Stough v. Brach, 395 Ill. 544, 7o N.E. $2 \mathrm{~d} 585$ (I946); Scherman v. Scherman, 395 Ill. 574, 7 I N.E. 2d 16 (x947); Houdek v. Ehrenberger, 397 Ill. 62, 72 N.E. 2d 837 (1947); Kane v. Johnson, 397 Ill. ×I 2, 73 N.E. $2 \mathrm{~d} 32 \mathrm{I}$ (1947).

${ }^{160} 395$ Ill. 402,70 N.E. $2 d 560$ (r946).

${ }^{26 x}$ Wrobel v. Wojlasiek, 34 I Ill. 330 , I73 N.E. 348 (1930) and cases cited in 48 A.L.R. 917 (1927). 
the agent, the purchaser was barred by the doctrine of mutuality from asserting a claim on the contract. Of the three authorities cited by the Court for the "settled principle," two were decided primarily on other grounds..$^{162}$ The value of the third ${ }^{163}$ as a precedent is questionable since it was ignored in a later case, on the same point, reaching a contrary result. ${ }^{164}$ The latter case was not cited in the instant opinion. Moreover, most commentators and many courts now agree that the doctrine of mutuality requires only that the court be able to grant complete relief to both parties. ${ }^{165}$ In the instant case, since the chancellor had ordered an assignment from the agent to the purchaser and the sale was for cash, the requirements of the doctrine could be satisfied. Finally, the line of decisions granting specific performance to a purchaser under a land contract signed only by the vendor ${ }^{\mathrm{x} 66}$ argue by analogy for granting specific performance here. The decision in the instant case, unfortunately, has added to the difficulty of the appellate judge who, referring to the doctrine of mutuality, once complained that "the decisions are not easy to harmonize." ${ }^{6} 67$

More far-reaching and practical effects may result from the third ground of the Court's decision. If followed, it would render the use of "straw men" in land transactions a perilous undertaking. Citing Cowan v. Curran, ${ }^{268}$ the Court said that specific performance was there denied because an undisclosed principal cannot sue where "exclusive credit" is given the one represented to be the purchaser. The Court then said that "in the same case we held in a contract of sale of real estate one has a right to determine with whom he will deal, and a failure to disclose an unknown, undisclosed principal is ground for denying specific performance." ${ }^{699}$ The holding that an undisclosed principal cannot sue where exclusive credit has been given to another is on its face much narrower than the proposition that failure to disclose an unknown principal is ground for denying

${ }^{162}$ Cummins v. Martzen, 273 Ill. 45, II 2 N.E. 347 (x9I6); Jacksonville Hotel Bldg. Corp. v. Dunlap Hotel Co., 350 Ill. 45 I, I83 N.E. 397 (1932).

${ }^{66} 6_{3}$ Lunt v. Lorscheider, 285 Ill. 589 , x2x N.E. 237 (xgr8).

${ }_{164}$ Lewis v. McCreedy, 378 Ill. 264,38 N.E. 2 d 170 (I94I).

${ }^{265}$ Stone, The "Mutuality" Rule in New York, I6 Col. L. Rev. 443, 446 (Igr6).

${ }^{666}$ Ullsberger v. Meyer, 217 IIl. 262, 75 N.E. 482 (I905); Gradle v. Warner, I40 Ill. I23, 29 N.E. III8 (I892); Estes v. Furlong, 59 Ill. 298 (I87r).

${ }^{167}$ Ellis Electrical Laboratory Sales Corp. v. Ellis, 269 Ill. App. 4r7, 426 (I933).

${ }^{368}{ }_{216}$ Ill. 598,75 N.E. 322 (IgO5). There the contract called for the advancement of six months' credit on a substantial part of the purchase price. The contract appeared to be signed by a Mrs. Kane, but, unknown to the vendor, Mrs. Kane's name had been signed by the defendant, the real party in interest.

${ }^{169} 395$ IIl. 402, 406, 70 N.E. 2d 560, 562 (1946). 
specific performance. Not one of eight foreign cases cited supports the proposition, ${ }^{170}$ and one was overruled on a second appeal. ${ }^{17 \mathrm{x}}$ Moreover, the Court in applying the narrower holding of the Cowan case apparently overlooked an essential fact. "In the present case," the Court said, "the contract was signed by Isabelle Ostrowski, and so far as appears sole credit was given to her by [the vendors]." ${ }^{172}$ A scrutiny of the contract discloses that not only was assignment contemplated but that the transaction was to be on a cash basis. ${ }^{x 73}$ It is to be hoped that the passage of time will not convert the Court's comments on the law of undisclosed principal into ratio decidendi. The use of straw men in land transactions is well settled in law and in business custom and is often the only way in which large corporations and governments can buy land without paying exorbitant prices.

The same lack of sensitivity to commercial needs was displayed in Ambarann Corp. v. Old Ben Corp. ${ }^{74}$ In that case, one Sinks, who originally held title to the land in controversy, conveyed the "coal, oil and gas" to the defendant, and later conveyed the property to the plaintiff's grantor, "saving and reserving all coal, oil and mineral rights as heretofore transferred to [the defendant]." The question at issue was the admissibility of usage evidence to prove that the words "coal, oil and gas" meant, in the locale in which the transaction took place, "coal, and all the oil and gas within the coal." The Court held that the surface owner was estopped to deny the recital of the reservation in the deed from his grantor and extrinsic evidence was inadmissible to prove that the intention of the parties was different from the "unambiguous" words. In doing so, the Court ignored the distinction between usage, which, according to most authorities, may always be admitted to explain even the most unambiguous language, and evidence of a private intention of the parties, which is barred by the parol evidence rule. The possible hampering effect of such an exclusionary rule in a great commercial state, where "unambiguous" words

${ }^{270}$ In four of the cases cited, specific performance was denied because of the agent's false representations: White Tower Management Co. v. Taglino, 302 Mass. 453, Ig N.E. 2d 700 (1939); Gloede v. Socha, I99 Wis. 503, 226 N.W. 950 (I929); New York Brokerage Co. v. Wharton, I43 Iowa 6r, rI9 N.W. 969 (1909); Winchester v. Howard, 97 Mass. 303 (r867). In two, the defendant had previously refused to deal with the undisclosed principal: Siess v. Anderson, I59 Mo. App. 656, I39 S.W. Ix78 (I9II); Boston Ice Co. v. Potter, I23 Mass. 28 (1877). Kane v. McClenachan, I04 Pa. Sup. 4I7, I59 Atl. 6I (1932), turned on the agent's duplicity. Kelly v. Thuey, I02 Mo. 522, I5 S.W. 62 (1890), involved the advancement of exclusive credit to the agent.

${ }_{77}$ Kelly v. Thuey, ${ }_{43}$ Mo. 422,45 S.W. 300 (I898).

${ }^{272} 395$ Ill. $402,407,70$ N.E. 2 d 560, 562 (r946).

273 Abstract of Record, at 77 .

${ }^{174} 395$ IIl. 154,69 N.E. $2 d 835$ (1946). 
and phrases may frequently have curious mercantile definitions, is evident. The cited cases are generally inconclusive ${ }^{175}$ and conflict with other Illinois decisions more in point. ${ }^{176}$ In view of the inconclusiveness of the authorities, it is unfortunate that the Court avoided this opportunity to discuss the persuasive arguments in favor of admissibility advanced by Wigmore $^{177}$ and Williston ${ }^{178}$ and accepted in the Restatement of Contracts. ${ }^{179}$ The Court's discussion of both estoppel and usage may have been dicta in view of the finding that, regardless of usage, the grantor actually had intended to convey the oil and gas in the first deed. The multiplicity of grounds for decision makes the Court's position on each of these points uncertain.

In Pearson v. Adams ${ }^{80}$ the Court was called upon to reconsider previous decisions denying an abatement of part of the purchase price where the vendor's wife refused to join in the deed. The Court has always taken the position that the value of a wife's inchoate right of dower is not ascertainable, even by the use of mortality tables. The plaintiff, however, pointed to a recent statute ${ }^{\mathrm{x} 8 \mathrm{x}}$ providing for a proceeding to determine the value of an outstanding inchoate dower right where real estate is sold on execution, or in bankruptcy, foreclosure, or lien enforcement proceedings. This, he argued, was evidence of a change in the public policy of the state on the subject. Most American jurisdictions prefer valuation of the dower interest to requiring the purchaser either to accept the deed without the wife's signature and later sue on the covenants, or to pursue his remedy at law for breach of contract. ${ }^{182}$ But the Court had a brief answer to the plaintiff's argument. "The statute relied upon singles out cases where there are involuntary sales and makes no reference to transactions volun-

${ }^{375}$ Gilbert \& Co. v. McGinnis, II IIl. 28, 28 N.E. 382 (I885), refused admission of evidence of a custom to give notes for advancements on the sale of corn. Morton v. Babb, 25 I Ill. 488, 96 N.E. 279 (IgrI) involved an attempt to alter the legal effect of a deed. The question of usage did not arise in Decatur Lumber \& Manufacturing Co. v. Crail, 350 Ill. 319 , I83 N.E. 228 (x932), Fowler v. Black, $x_{3} 6$ Ill. 363 , 26 N.E. 596 (I89x), or Ford v. Witwer, 383 Ill. 5 II, 50 N.E. $2 d 7 x_{4}(1943)$.

${ }^{276}$ In Steedtman v. Joseph Lay Co., 234 Ill. 84,84 N.E. 640 (Igo8), it was held error to exclude evidence of usage to interpret the meaning of such phrases as "f.o.b. Ridgeville, Indiana," and "free at Ridgeville, Indiana." In Leavitt v. Kennecolt, 157 IIl. 235, 4I N.E. 737 (1895), an action for breach of contract to employ plaintiff "at a weekly salary of forty dollars per week," it was held error to exclude evidence of a custom not to pay during the summer.

${ }_{777} 9$ Wigmore, Evidence, $\$ 2462$ (1940).

${ }_{778} 3$ Williston, Contracts $\$ \S 609,629\left(x_{93} 6\right)$.

I79 Rest., Contracts $\$ \$ 246-48$ (I932).

${ }^{280} 394$ Ill. 39 I, 68 N.E. 2 d 777 (I946). I8x III. Rev. Stat. (I945) c. 3, \& I89.

${ }_{182}$ See cases collected in ${ }^{4} 8$ A.L.R. 292 (I944) and 46 A.L.R. 749 (I927). 
tarily entered into by the parties." ${ }^{83}$ The policy evinced by the statute might be interpreted to proffer to the Court an opportunity to bring Illinois law into the majority fold. On the other hand, no one would argue that the value of a particular dower right can be accurately determined. The Court evidently believed that the necessarily arbitrary decision should be made only in the situations set forth in the statute.

A tendency to require strict performance of a contract for the purchase of land is manifested in Johnson v. Riedler. ${ }^{\mathrm{x} 4} 4$ The contract provided for payment of the purchase price within five days after the title was shown to be merchantable. A controversy developed as to the place of payment and delivery of the deed and tender of the purchase money was delayed until one month after the time stipulated. The Court held that the plaintiff was not entitled to relief since he could not show that he had fully performed his part of the bargain. In two of the cases cited by the Court, time was made of the essence by the parties. ${ }^{85} \mathrm{~A}$ third involved a lapse of performance of several years. ${ }^{186}$ The present case thus goes further than these authorities in requiring strict compliance with a contractual provision as to time of performance where the parties have not made time of the essence. In the remaining real property cases, the Court reasserted well-established rules and applied them to the facts presented. ${ }^{187}$ Few of those cases were worthy of the attention of the highest judicial body of the state.

Several administrative provisions of the Probate Act were considered by the Court in the period under review. Two cases involved the situation created in the Probate Court of Cook County by provisions of the Illinois Constitution permitting only one probate court and one probate judge in the county. ${ }^{188}$ An unbearable burden is imposed upon this single judge by the provision of the Probate Act requiring that each of the two attesting

${ }^{88_{3}} 394$ Ill. 39r, 399, 68 N.E. $2 \mathrm{~d} 777,78$ I (1946).

${ }^{284} 395$ Ill. 4I2, 70 N.E. 2 d 570 (1946).

${ }^{285}$ Olson v. Forsberg, 332 Ill. 266, I63 N.E. 697 (I928); Mitchell v. White, 295 Ill. I35, I28 N.E. 803 (1920).

${ }^{186}$ Bennett v. Burkhalter, 257 Ill. 572, Ior N.E. I89 (1913).

${ }^{287}$ McCleary v. Lewis, 397 Ill. 76, 72 N.E. 2 d 862 (I947); Spies v. De Mayo, 396 Ill. 255, 72 N.E. $2 d$ I 36 (I947); Bydalek v. Bydalek, 396 Ill. 65, 7 I N.E. 2 I 19 (I947); Lewis v. Blumenthal, 395 Ill. 588, 7 I N.E. 2d 36 (1947); Creighton v. Elgin, 395 Ill. 87 , 69 N.E. $2 d$ for (1947); Rice v. United Mercantile Agencies, 395 Ill. 5 I2, 70 N.E. 2 d 618 (1946); Koslowski v. Mussay, 395 Ill. 8I, 69 N.E. 2d 338 (1946); Schueler v. Blomstand, 394 Ill. 600, 69 N.E. 2 d 328 (r946); Newman v. Youngblood, 394 Ill. 617,69 N.E. 2d 309 (r946); Hesker v. Shaffer, 394 IIl. 489, 68 N.E. 2d 612 (1946).

183 Ill. Const. Art. VI, 820. 
witnesses to a will testify before the probate court prior to admission of the purported will to probate.$^{89}$ As a result, the Cook County Probate Court has adopted an expedient whereby the deputy probate clerk hears the testimony of the subscribing witnesses, and the probate judge thereafter merely certifies a transcript of the testimony. In neither case did the Court actually pass on the legality of this expedient. In the first, ${ }^{\text {,90 }}$ the Supreme Court reiterated its previous position that the validity of a probate court order may not be collaterally attacked in a will contest, ${ }^{x 9 x}$ pointing out that the right to contest a will exists only under Section 90 of the Probate Act, ${ }^{\mathrm{xg}}$ which does not authorize collateral actions attacking the procedure admitting the will to probate. ${ }^{x 93}$ In the second case, ${ }^{194}$ a petition for mandamus to compel the probate judge to expunge from the records all entries pertaining to the admission of a will and codicils to probate was held to have been properly denied. The extraordinary remedy of mandamus could not be used to correct an allegedly improper procedure when the probate proceedings were not void and when no reason was given for the failure to object at the proper time and to appeal from the probate court's decision as provided by statute. ${ }^{95}$ The Court had previously refused to admit parol testimony contradicting similar certificates of the probate judge where transcripts of the testimony of subscribing witnesses taken in the probate court were offered as evidence in a circuit court. ${ }^{196}$ The Court there made its position clear when it said, "If it was not taken in open court, as she now contends the law requires, it was her duty then to object." ${ }^{297}$ While it is regrettable that the inaction of the legislature makes this extra-legal procedure necessary in Cook County, the Court's decisions are well in line with long-established authority refusing

${ }^{189}$ Ill. Rev. Stat. (I945) C. $3, \S 221$.

${ }^{190}$ Kula v. Sitkowski, 395 Ill. I67, 69 N.E. 2d 688 (1946).

${ }^{79 x}$ Shelby Loan \& Trust Co. v. Milligan, 372 Ill. 397, 24 N.E. $2 d$ I 57 (1939); Dowling v. Gilliland, 275 Ill. 76, Ir $_{3}$ N.E. 987 (IgI6).

${ }^{192}$ III. Rev. Stat. (I945) c. $3, \S 242$.

${ }^{293}$ Section 90 of the Probate Act provides for an action ". . . to contest the validity of the will. ....."Ill. Rev. Stat. (1945) c. $3, \$ 242$. The section was derived from Section 7 of the Wills Act of 1872 as last amended by Ill. I. I935, p. I442, $\S \mathrm{I}$, which reads in part, ". . . an issue at law shall be made up whether the writing produced be the will of the testator or testatrix or not....."

${ }^{29}$ People v. O’Connell, 394 Ill. 4 \%9, 68 N.E. $2 d 758$ (1946).

195 Ill. Rev. Stat. (I945) c. $3, \$ 8483,484$.

${ }^{396}$ Teter v. Spooner, 279 Ill. 39, Ir6 N.E. 673 (I9r7); Wilkinson v. Service, 249 Ill. r46, 94 N.E. 50 (IgII).

${ }^{197}$ Wilkinson v. Service, 249 Ill. $146,154,94$ N.E. 50, 53 (Igrr). 
to void a judgment for procedural defects when no appeal had been taken. ${ }^{98}$

Another question of procedural technique was raised in Dickman v. Frieling, ${ }^{199}$ in which a devisee under a will executed prior to the marriage of the testator and admitted to probate by a county court brought suit for partition of the real property devised. The defendant, recognizing that when a county court having jurisdiction admits a will to probate the decree is conclusive until set aside on appeal or by a judgment in a statutory will contest, argued that when the testator remarried, the will was revoked by Section 46 of the Probate Act, ${ }^{200}$ and that since there was no will, there was no subject matter over which the probate court could exercise jurisdiction. The Supreme Court rejected this argument on the basis of previous decision, ${ }^{20 x}$ but did not make the obvious answer that a court with probate jurisdiction has jurisdiction over all purported wills. The result, which prevents the injection of a will contest into partition proceedings, is supported by the policies which require that an end be brought to litigation and that security of titles be maintained. ${ }^{202}$

The Court also considered several cases during the last term involving substantive provisions of the Probate Act. Bruce v. McCormick ${ }^{203}$ raised the question of the interest acquired by a surviving spouse before the expiration of the period provided for the perfection of dower in Section Ig of the Probate Act. During this period, the widow of a decedent had executed and delivered a quitclaim deed for a piece of land of which her intestate husband had been the owner. The grantee conceded that under the old Dower ${ }^{204}$ and Descent Acts ${ }^{205}$ the vesting in the surviving spouse of an undivided one-third fee interest in the real property was conditioned upon specific waiver or failure to elect to take dower within the statutory period, but claimed that the Probate code which repealed these earlier acts ${ }^{206}$ vested an undivided one-third interest in fee in the survivor, subject to a condition subsequent that she not perfect her right of dower within the

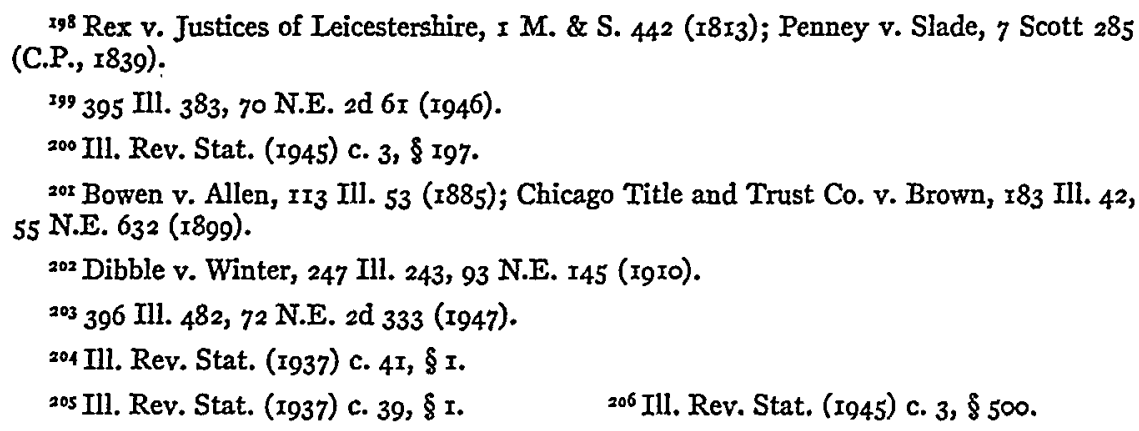


permitted time. The Court held that Sections II, ${ }^{207}$ I $8,,^{208}$ and $I 9,209$ merely codified and simplified the corresponding provisions of the Dower and Descent Acts, and that the widow had only an unperfected dower interest which was not capable of being conveyed to a stranger to the fee. ${ }^{200} \mathrm{How}-$ ever, Sections II, 18 , and 19 of the Probate Act were intended to provide that the survivor obtains a fee interest if he takes no action to perfect his dower, instead of obtaining a dower interest if he fails to claim his intestate share. ${ }^{2 I}$ The Court has partially defeated the purpose of the legislation in failing to read Sections 18 and $x_{9}$ in the light of this important change. The decision is also regrettable in that it immobilizes land in which dower rights may exist and permits a surviving spouse to defeat his own conveyance.

Construing Sections 85 and 89 of the Probate Act in a statutory will contest, the Court held in Sternberg v. St. Louis Union Trust Co., ${ }^{272}$ that a foreign will, insofar as it purported to devise Illinois real estate, was revoked by the marriage of the testator after execution of the will, although the testator was a resident of another state and the will was admitted to probate under the provisions of Section 85 . Section 89 was interpreted as intended only to protect the foreign will from collateral attack. A foreign will is given the same status as a domestic will and although admitted to probate it remains subject to direct attack. This result is supported by traditional techniques of statutory construction. Section 89 provides that "the admission to probate" of a foreign will "has the same effect in all respects as the admission to probate of a domestic will." The term "probate" is used in Article V of the act to refer to the provisional admission by the probate court. The section in question follows in Article VI and the legislature may have intended to use the term in the same manner. Doubt is cast upon this result, however, by the fact that the term may also mean the totality of the proceedings in which the effectiveness as a will of a paper purporting to be a will is finally determined. This meaning

${ }^{207}$ Section II of the Probate Act provides that when there is a surviving spouse and also a descendant of the decedent, the spouse takes one-third of each parcel of real estate in which he does not perfect his right to dower. Ill. Rev. Stat. (1945) c. 3, \& 162.

${ }^{208}$ Section 18 of the. Probate Act gives the surviving spouse a one-third interest in all real estate "unless the dower has been released or is barred." Ill. Rev. Stat. (I945) c. 3, § I7o.

${ }^{209}$ Section Ig of the Probate Act provides that the dower is barred unless perfected in a specified manner within ten months after the issuance of the letters of administration. Ill. Rev. Stat. (I945) c. 3, \& I I.

${ }_{2 \pi 0}$ O'Malley v. Deany, 384 IIl. 484, 5 I N.E. 2d 583 (I943).

2Ir James, Illinois Probate Act Annotated 3 I (I940).

${ }_{222} 394$ Ill. 452, 68 N.E. 2d 892 (I946). 
includes the probate proceedings under Article $V$ and the will contest combined. Since the only questions which might be raised in Illinois and not in the foreign jurisdiction are those pertaining to formalities, and since those limitations appear to be waived by Section 85 , it seems strange that a direct attack in a will contest is allowed. The Court did not discuss this question.

In construing Section 96, which lists the priority for appointment of members of various classes as administrators, the Court held that where heirs (members of class five) are in such position that, if appointed administrators de bonis non, they would be opposing as individuals what they were required to do as administrators, a probate court has jurisdiction to determine that the statute giving heirs preferential rights of administration must yield to the paramount necessity of accomplishing substantial justice between the parties in interest by appointment of a disinterested third person at the request of creditors (class eight). ${ }^{2{ }^{2} 3}$ The Court said, "... the statute neither expressly nor by implication confers an absolute right on persons within one of the enumerated classes to be appointed administrator." ${ }^{2 \times 4}$ The fact that the heirs objected to the sale of real estate in order to discharge debts was considered a sufficiently strong adverse interest to make them unsuitable to administer, even though such adverse interest is not specified in Section 94 as a disqualifying factor. By holding that the disqualifications embodied in Section $95^{255}$ are not exclusive, the Court reached a reasonable result and left open the possibility of recognizing similar considerations which may arise in the future applications of Section 96 .

Besides the problems arising under administrative and substantive sections of the Probate Act, the Court also considered several problems connected with decedents' estates which arose apart from the statute. The cases on mental capacity and undue influence rely on earlier decisions to defeat disinherited relatives clutching at legal straws to overthrow wills. ${ }^{260}$ The three cases dealing with construction of wills show the Court strug-

223 In re Estate of Abell, 395 Ill. 337, 70 N.E. 2d 252 (I946).

254 Ibid., at 346 and 256 .

215 "A person is not qualified to act as administrator of the estate of any decedent if he is of unsound mind or an adjudged incompetent under this Act or has been convicted of a crime rendering him infamous or is a nonresident of this state, or, if a male, is less than twenty-one years of age or, if female, is less than eighteen years of age. Any corporation qualified to accept and execute trusts in this state is qualified to act as administrator." Ill. Rev. Stat. (1945) c. $3, \S 246$.

${ }_{216}$ Schlachter v. Schlachter, 396 Ill. I84, 7 I N.E. 2d 153 (1947); Challinger v. Smith, 396 IIl. I06, 7 r N.E. 2d 324 (I947); Johnson v. Bennet, 395 Ill. 389, 69 N.E. $2 d 899$ (1946). 
gling to carry out the intent of the testators. In Geiger v. Geer ${ }^{227}$ the Court stated that will construction decisions are necessarily limited to their own facts and paid little attention to the available precedents in deciding the case, whereas in Frendenstein v. Braden ${ }^{2 \mathrm{r} 8}$ the Court relied heavily on earlier cases.

In a third case, Bozza v. First National Bank of Alton, ${ }^{2 \mathrm{~g}}$ the testator devised an estate in trust to pay the income to his wife for life, and on her death to pay income to his four children for life, and on the death of the last of the four children to distribute the corpus to the testator's living grandchildren and the descendants of any deceased grandchildren. The testator's widow, children, and grandchildren brought suit to accelerate distribution of the corpus on the grounds that the advanced ages of the four children precluded the birth of more remaindermen. The Court refused to terminate the trust on the ground of the legal presumption of the possibility of issue until death. The precedents utilized by the Court stem from Hill v. Spencer, ${ }^{220}$ in which it was said as dictum, without citing cases, that "the allegation that Martha Hill [the grantee] is past the time of life to have children is meaningless, as she is, in law, presumed to be capable of bearing children as long as she live, unless more than a mere matter of age is stated in the bill." ${ }^{3222}$ It is likely that this dictum stems from the cases involving the rule against remoteness of vesting. ${ }^{222}$ If so, the Bozza case postpones the vesting of a remainder by applying a rule against the remoteness of vesting. Because of the dubious precedent, it is unfortunate that the Court did not analyze the facts in the Bozza case in an attempt to create a rational rule. It did attempt to base its decision on policy considerations by saying that, although an irrebuttable presumption such as child-bearing capacity is not to be favored, a contrary rule would encourage life tenants to undergo sterilization in an attempt to accelerate distribution. It is to be regretted that the doctrine on possibility of issue has been carried over to new problems without more critical examination.

Of the few family relations cases reaching the Supreme Court last year, the most important dealt with divorce. The Supreme Court in Conrad v. Conrad $^{223}$ held that a city court had jurisdiction to grant a default decree

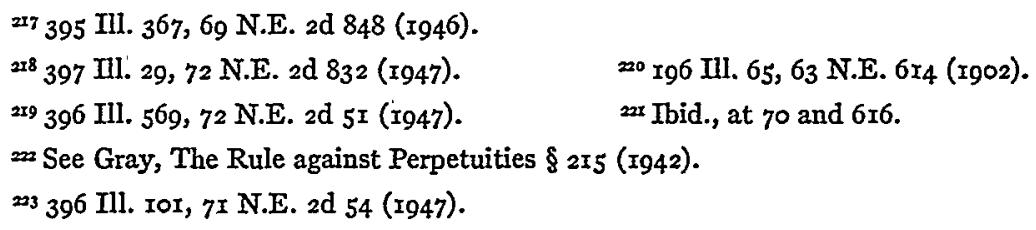


of divorce for desertion commencing outside the state, where the plaintiff had resided in Illinois for more than a year and in the city for nearly a year before filing the complaint. The decision is significant because it is the first application to a divorce case of the rule of Werner v. Illinois Central R. Co. ${ }^{224}$ which decided that under the Illinois Constitution ${ }^{225}$ and Section $I$ of the City Court Act, as then in force, ${ }^{226}$ city courts have no jurisdiction over causes of action arising outside the territorial limits of the city. The action there was for personal injury under the Federal Employers' Liability Act, but the rule was stated to be of general application.

Determination of the place where a cause of action arises is not a factual, but a legal problem, frequently requiring application of artificial rules such as those used in conflict of laws for determining the place of contracting or the place of harm. Generally it is said that a cause of action arises at the time when, and at the place where, there occurs the last in the chain of events constituting the operative facts upon which the law predicates the cause of action. ${ }^{227}$ Under this theory, a cause of action for divorce arises when and where the last event happens which is necessary by statute to entitle the plaintiff to a decree. Where, as in Illinois, at least two acts of physical cruelty are required for a divorce on the ground of extreme and repeated cruelty, the plaintiff's cause of action arises when and where the second act is committed against him. Where an alleged wrongdoer acts in one place but the harmful effect is felt in another, the latter place is regarded by orthodox theory as the place of wrong. ${ }^{228}$

Thus in the Conrad case the Court held that the cause of action arose in West Frankfort, where the plaintiff resided at the time the act of deser-

224379 Ill. 559, 42 N.E. 2 d 82 (1942).

zas Ill. Const. Art. VI, $\S \mathrm{I}$.

${ }_{22}^{6}$ Ill. Rev. Stat. (I94I) c. $37, \S 333$. This section was amended in 1943 to eliminate the words "[The city court] shall have concurrent jurisdiction with the circuit court within the city in ... . [all] cases arising in said city" and to substitute "shall be courts of general jurisdiction in and for the cities wherein they are respectively established, in all . . . cases. . . . "Ill. I. I943, at 578. A very recent case in an Appellate Court, Govan v. Govan, 73 N.E. 2 d I63 (I947), holds that the amendment eliminates the whole problem of the Werner case by omitting the words "arising in said city." But the constitutionality of the amended statute so construed is questionable. According to the discussions in the Werner case and in McFarlin v. McFarlin, 384 Ill. 428, 5 I N.E. 2 d 520 (I943), tracing the rule first laid down by People ex rel. Beebe v. Evans, I8 Ill. 36I (1857), the words "in and for cities" under Art. VI, \& I of the Constitution, have consistently been interpreted as being equivalent to "arising in said city."

${ }_{227}$ Rest., Conflict of Laws \$§ 3II-3I (1934); Rheinstein, The Place of Wrong, I9 Tul. L. Rev. 4 (I944).

228 Alabama Great Southern R. Co. v. Carroll, 97 Ala. r26, II So. 803 (I892); Worster v. Winnipiscogee Lake Co., 25 N.H. 525 (I852); The Plymouth, 3 Wall. (U.S.) 20 (I865); United States v. Davis, Fed. Cas. No. 14,932 (1837). 
tion became complete in Illinois, although the other party had never been there. It would seem to follow that the plaintiff could sue in no other city court, even if he should later become a resident of another city. Whether a cause of action may be said to arise also where the acts or conditions complained of were committed or begun is still an open question. For example, if a wife commits adultery in City A, while her husband resides in City B, can he sue in City A? Or, if the second act of cruelty occurred in City A although the parties resided in City B, could the suit be brought in City A? Whatever the merits of this conceptualistic rule as to where a cause of action arises, one may suspect that its adoption will create many headaches in future litigation. ${ }^{229}$

In Ollman v. Ollman ${ }^{230}$ the Court reiterated the definition of condonation generally accepted in the United States, as a conditional forgiveness of past offenses, the effect of which is to bar a suit for divorce based thereon. ${ }^{23 \mathrm{~T}}$ In this case the husband had left home after commission of the only acts of cruelty alleged as grounds for divorce. Subsequently there was a reconciliation and the parties cohabited, not happily but without violence, for many months. The Court only followed the clear line of authority in holding that the reconciliation and cohabitation constituted condona$\operatorname{tion}^{232}$ and that under the strict Illinois rule the subsequent bickering and antagonism neither revived the old offense ${ }^{233}$ nor amounted to new acts of cruelty. ${ }^{234}$

In the same case the Court clarified a point confused by dicta in previous cases. ${ }^{235}$ Condonation was not pleaded as a defense, and all the evidence of condonation was in the plaintiff's own testimony. Some courts have held that condonation is an affirmative defense and must be pleaded

229 For a study of the jurisdiction of city courts as it affects the current problem of Chicagoans seeking divorces in Calumet City see Divorce Cases in City Courts, $28 \mathrm{Chi}$. Bar Rec. I6r (1947).

${ }^{230} 396$ Ill. $x 76,7$ I N.E. $2 d$ 5o (1947).

${ }_{233}$ Young v. Young, 323 Ill. 608, I54 N.E. 405 (I926); Abbott v. Abbott, I92 Ill. 439, 6r N.E. 350 (I IOI).

${ }_{232}$ Moore v. Moore, 362 Ill. 177, I99 N.E. 98 (I935); Abbott v. Abbott, I92 IIl. 439, 6I N.E. $35^{\circ}$ (I90r); Duberstein v. Duberstein, I7x Ill. 133, 49 N.E. 316 (I897); Youngs v. Youngs, I30 Ill. 230, 22 N.E. 806 (I889).

233 Young v. Young, 323 Ill. 608, I54 N.E. 405 (I926); Abbott v. Abbott, I92 Ill. 439, 6I N.E. 350 (190r); Farnham v. Farnham, 73 Ill. 497 (I879); cf. Lipe v. Lipe, 327 Ill. 39 , 158 N.E. 4 II $\left(\mathrm{r}_{927}\right)$.

${ }_{234}$ Trenchard v. Trenchard, 245 Ill. $33^{\text {I3 }}, 92$ N.E. 243 (I9I0); Fizette v. Fizette, I $_{4} 6$ Ill. 328, 34 N.E. 799 (I893); Wesselhoeft v. Wesselhoeft, 369 Ill. 4I9, x7 N.E. $2 \mathrm{~d} 56$ (I938); Teal v. Teal, 324 Ill. 207, I55 N.E. 28 (I927).

${ }^{235}$ Lipe v. Cipe, 327 Ill. 39, I 58 N.E. 4 II (I927); Klekamp v. Klekamp, 275 IIl. 98, II3 N.E. 852 (IgI6). 
as such. ${ }^{236}$ But the cases show that this statement must be taken to mean only that the defendant may not, as a matter of right, raise the issue of condonation when the defense has not been pleaded. The Supreme Court pointed out that in divorce suits, unlike most other civil actions, the state is an interested third party, and that the court's duty therefore is to uphold the public policy in favor of preserving the marriage relation by denying divorce, regardless of procedural rules, if it appears that not all the state's requirements for divorce are satisfied. ${ }^{237}$

All labor law cases decided during the I946-47 terms involved claims under the Workmen's Compensation and Unemployment Compensation Acts by workers or their beneficiaries. No cases arose under the state antiinjunction act, nor did any case involve the legality of union activity.

The perennial problem of defining the scope of employment for purposes of workmen's compensation and unemployment compensation was an issue in a number of cases in which the Court consistently opposed attempts by the compensation commissions and the lower courts to loosen the limiting bounds of coverage. The decisions indicate a cautious conservatism in judicial interpretation of social legislation. In one case the Court denied compensation on the ground that a fatal railroad injury had not arisen out of the employment where a worker drove 650 feet out of the way to check on the safety of his children. ${ }^{28}$ If the deceased had gone home for lunch, ${ }^{239}$ or if he had returned to the employer's premises when injured ${ }^{240}$ or if the deviation had been a practice condoned by the employer, ${ }^{24 x}$ recovery probably would have been allowed. In another case, where an employee was struck by a co-worker wielding a soup ladle, ${ }^{242}$ the Court set aside his compensation award for the loss of an eye, stating that the hazard of such an attack was not a risk incidental or peculiar to the employment but was rather a risk common to the general public.

${ }^{236}$ Wallace v. Wallace, II 2 N. J. Eq. 292, 164 Atl. 565 (r933); Clark v. Clark, I43 Okla. 9 I, 287 Pac. 721 (I930); Tarr v. Tarr, I84 Va. 443, 35 S.E. 2d 40I (I945); Eldridge v. Eldridge, 278 Mass. 309 , I80 N.E. I37 (I932); Nelson v. Nelson, 208 Iowa 7x3, 225 N.W. 843 (I929); Blakely v. Blakely, 186 N.C. $35 x$, II9 S.E. 485 (1923); Skinner v. Skinner, 47 Ind. App. 670 , 95 N.E. I 28 (IgII).

237 Johnson v. Johnson, 38 I Ill. 362,45 N.E. $2 d 625$ (1942); Winning v. Winning, 366 IIl. 57, 7 N.E. 2d 750 (I937); Decker v. Decker, I93 Ill. 285, 6r N.E. x 108 (xgor).

6 ${ }_{238}$ Public Service Co. v. Industrial Comm'n, 395 Ill. 238, 69 N.E. 2 d 875 (1946).

239 Porter Co. v. Industrial Comm'n, 301 Ill. 76, I33 N.E. 652 (I92I).

${ }^{340}$ Schafer v. Industrial Comm'n, 343 Ill. 573, I75 N.E. 789 (I939).

${ }_{24}$ Pressed Steel Car Co. v. Industrial Comm'n, 340 Ill. 68, r72 N.E. 52 (1930).

${ }^{242}$ Math Igler's Casino, Inc. v. Industrial Comm'n, 394 Ill. 330, 68 N.E. 2d 773 (1946). 
However, had the petitioner's fellow employee swung the soup ladle playfully rather than maliciously, the Illinois Court probably would have held that the injury arose out of the employment. ${ }^{243}$ While the Court apparently is willing to recognize that the work situation inspires man's natural bent for play, it will not recognize that industrial life may similarly whet aggressive feelings. A number of states have awarded compensation in assault cases, two on the ground that the employment exposed the worker to the attack, ${ }^{244}$ and two others by inferring without specific evidence that there was a causal connection between the work and the assault.245

The Compensation Act provides that any right to receive compensation is extinguished by the death of the injured employee due to causes other than the injury. But if, before the employee's death, an award is determined for a specific loss, his dependents are entitled to the balance remaining due. ${ }^{246}$ In a recent case.loss of sight was held to be such a specific loss, ${ }^{247}$ but in two other cases, because the award determination had not been finally concluded by the commission before the employee's death, the awards to the widows were set aside..$^{28}$ The Court's approach in these cases may perhaps be explained as a refusal to extend beyond its narrowest limits a legislative concession antagonistic to the basic rationale of workmen's compensation - that loss suffered because of the job should be charged to the job. Allowing payment for a reduced earning potential due to an incapacity caused by a work injury, after the incapacitated claimant dies from another cause, amounts to paying for that part of a potential loss which never actually materialized. The rationale more apparent in the decisions, however, is that if an award were to be made final on the arbitrator's finding alone, the employer would be deprived of the protective privilege of a commission hearing with the attendant medical and testimonial examination of the claimant.

Another group of decisions during the I946-47 sessions dealt with the scope of review of Industrial Commission findings. Although the Supreme Court has plenary power to review such findings, three cases show the Court's willingness to accept Commission determinations where there was

${ }_{243} \mathrm{Cf}$. International Harvester Co. v. Industrial Comm'n, 354 IIl. I5I, 187 N.E. 916 (1933). ${ }_{244}$ Anderson v. Hotel Cataract, 17 N.W. 2d $91_{3}$ (S.D., 1945); Ferguson v. Cady-McFarland Gravel Co., I56 La. 87x, Ior So. 248 (x924).

${ }_{245}$ York v. City of Hazard, $30 \mathrm{~K} \mathrm{Ky.} \mathrm{306,} \mathrm{Igr} \mathrm{S.W.} 2 \mathrm{~d} 239$ (r945); Grossberg v. H. \& H. Taxi • Corp., 250 App. Div. 804, 294 N.Y. Supp. 20I (r937).

${ }^{24} 6 \mathrm{Illl}$. Rev. Stat. (1945) C. 48, \& $\mathrm{r}_{45}(\mathrm{e})(\mathrm{rg})$.

${ }_{247}$ Mt. Olive \& Staunton Coal Co. v. Industrial Comm'n, 394 Ill. 377, 68 N.E. 2d 77 (I946). ${ }_{248}$ Neumann v. Industrial Comm'n, 396 Mll. 224, 7 IN.E. $2 \mathrm{~d}$ I68 (r947); Pullman-Standard Car Mfg. Co. v. Industrial Comm'n, 396 Ill. 386, 7 I N.E. 2d 697 (I947). 
conflicting testimony of medical experts as to the cause of the injury..$^{249} \mathrm{In}$ these cases the Court says that it does not reverse the findings of the Commission "unless manifestly against the weight of the evidence," and appears to consider this rule equivalent to the usual substantial evidence rule. ${ }^{250}$ Yet in all cases except those where the Court prefers to stage the battle of experts in another arena, judicial review of the findings of the Industrial Commission has many of the aspects of a new trial. ${ }^{25 x}$

Another general question considered by the Court was whether a claimant qualifies as an "employee" within the provisions of the Workmen's Compensation Act. Although the statutory definition of "employee" is broad in Illinois, the concept of the "independent contractor" remains a vital and effective doctrine to defeat claims. In a recent case the Court held that each case must be decided upon its own facts, with no one feature determinative of the relationship. ${ }^{252}$ It did, however, emphasize that the most important feature is the right of the employer to control the manner of work. The Court placed the burden upon the claimant to establish, by a preponderance of evidence, "all the essential elements of a contract of employment," including the fact that the worker was an "employee" rather than an "independent contractor." that a more apt comparison may be made with the treatment of whether or not employment is "casual," in which case the burden has been placed upon the compensation claimant to prove employment and injury, but on thexemployer to prove that the employment was merely casual. ${ }^{254}$

When is a worker an "independent contractor" within the meaning of the state Unemployment Compensation Act? Recent cases show that a worker who might be considered ineligible for compensation under the Workmen's Compensation Act as an independent contractor and not an employee might easily be considered "in employment" for purposes of de-

${ }^{349}$ Olin Industries v. Industrial Comm'n, 394 Ill. 593, 69 N.E. 2d 305 (r946); Cruthis v. Industrial Comm'n, 394 Ill. 506, 68 N.E. 2d 744 (1946); Moergen v. Industrial Comm'n, 394 IIl. 383,68 N.E. 2 d 740 (1946).

${ }^{250}$ Grola v. Industrial Comm'n, 388 Ill. II4, I23, 57 N.E. 2d 373, 377 (I944).

${ }^{255}$ Stern, Review of Findings of Administrators, Judges, and Juries, 58 Harv. L. Rev. 70, 89 (1944).

${ }_{252}$ Immaculate Conception Church v. Industrial Comm'n, 395 Ill. 6r5, 7I N.E. 2d 70 (I947).

${ }_{253}$ Chicago Hardware Foundry Co. v. Industrial Comm'n, 393 Ill. 294, 65 N.E. $2 d 778$ (1946); Western Cartridge Co. v. Industrial Comm'n, 383 Ill. 23r, 48 N.E. 2 d 938 (1943); Northwestern Yeast Co. v. Industrial Comm'n, 373 Ill. x95, 37 N.E. $2 d$ 806 (I94r); Borgeson v. Industrial Comm'n, 368 Ill. 188 , I3 N.E. $2 d$ 164 (I938).

254 Consumers Mutual Oil Producing Co. v. Industrial Comm'n, 289 Ill. 423, I24 N.E. 608 (IgI9); Chicago Great Western R. Co. v. Industrial Comm'n, 284 Ill. 573, I20 N.E. 508 (rgI8). 
riving benefits under the Unemployment Compensation Act. ${ }^{255}$ That the construction given the two acts seems inconsistent has been recognized by the Court, and is justified by the differences in their basic purposes. ${ }^{256}$ But the real reason for differences in construction is the presence in the Unemployment Compensation Act of specific standards defining the scope of the Act. ${ }^{257}$ These were construed in Concrete Materials Corp. v. Gordon ${ }^{258}$ where the independent contractor issue turned on the application of the statutory definitions.

The Unemployment Compensation Act denies benefits to workers unemployed because of a labor dispute. ${ }^{259} \mathrm{~A}$ walkout in objection to the refusal of the employer to accept the employees' interpretation of contract provisions relating to vacation and portal-to-portal pay was held to result in unemployment due to a labor dispute, and claims for unemployment benefits were therefore refused. ${ }^{260}$ The argument for the claimants was that in this case no labor dispute existed because the strike supported a demand for a benefit which had already been conceded. The Court rejected this contention on the ground that such conduct came within the all-inclusive definition of a labor dispute under the Norris-LaGuardia Act.

\section{PROCEDURE AND EVIDENCE}

Only one procedure case and a few evidence cases decided during the last year appear worthy of comment. Reiter v. Illinois National Casualty $\mathrm{Co}^{26 \mathrm{r}}$ clears up an ambiguity and anachronism in the Civil Practice Act. ${ }^{262}$ In an action in equity the defendant moved to dismiss at the close of the plaintiff's evidence. The trial court granted the motion, but the appellate court reversed and remanded with directions to enter a decree for the plaintiff. ${ }^{263}$ In an action at law on reversal and remandment the defendant would have had an opportunity to submit his evidence. But the ap-

${ }_{255}$ Van Ogden, Inc. v. Murphy, 390 Ill. I33, 60 N.E. $2 d 877$ (1945); Peasley v. Murphy, 38 I Ill. 187, 44 N.E. 2d 876 (I942); A. George Miller, Inc. v. Murphy, 379 Ill. 524, 42 N.E. 2d 78 (r942); see Crouch v. Murphy, 390 Ill. II2, 60 N.E. 2d 879 (1945); Karlson v. Murphy, 387 IIl. 436,56 N.E. 2 d 839 (I944).

${ }^{256}$ Panther Creek Mines v. Murphy, 390 Ill. 23, 60 N.E. 2d 217 (1945).

257 Ill. Rev. Stat. (I945) c. $48, \S 218$ (d)(e)(f).

${ }_{258} 395$ Ill. 203,69 N.E. $2 d 84$ I (1946). $\quad 259$ Ill. Rev. Stat. (1945) c. $48, \S 223$ (d).

${ }_{260}$ Local Union No. II v. Garden, 396 Ill. 293, 7 I N.E. 2d 637 (1947).

${ }^{26 \mathrm{x}} 397$ IHl. I4I, 73 N.E. 2d 4I2 (I947).

${ }^{262}$ Compare Johnson v. Johnson, 38r IIl. 362, 45 N.E. 2d 625 (r942), and Havill v. Darch, 320 Ill. App. 667,52 N.E. 2d 64 (1943), with Kanauske v. Clark, 388 Ill. 357,57 N.E. 2 d 890 (1944); see also 42 Ill. L. Rev. 228 (1947).

${ }^{263}$ Reiter v. Illinois National Casualty Co., 328 Ill. App. 234,65 N.E. $2 d$ 93० (1946). 
pellate court reasoned that in equity the defendant's motion to dismiss submitted the case on the plaintiff's evidence alone and waived the right to submit evidence after reversal. It adopted the Supreme Court's dictum that Section 64(4) of the Practice Act, "If the decision on the motion is adverse to the defendant he may proceed to adduce evidence in support of his defense ....," did not change the rule where the trial court's decision was favorable to the defendant. The Supreme Court on rehearing reversed the appellate court and its own first opinion, holding that under Section 74 an appeal is a continuation of the proceeding below so that, under Section 64(4), the reversal in the appellate court was a decision "adverse to the defendant." This holding seems a workmanlike elimination of an unnecessary difference between the practice in law and equity and anticipated an amendment to the Practice Act which achieved the same result. ${ }^{264}$

Although the Illinois Supreme Court ruled on incidental questions of evidence in many cases during the $1946-47$ terms, only the few in which decision turned solely on the evidence point are discussed in this section. In People v. Sims ${ }^{265}$ the Court dealt with the admissibility of a confession obtained from a seventeen-year-old girl while a lie detector was attached to her arm against her wishes. Her request for counsel had been denied. While, unknown to the girl, the detector was not operating, she confessed. The Court held the admission of the confession by the trial court reversible error, saying, "The lie detector was used illegally and . . . . its application influenced, if it did not induce, the confession." ${ }^{266}$ Presumably, this ruling was based on a broad policy of excluding illegally obtained evidence, ${ }^{267}$ rather than a belief that confessions so obtained are untrustworthy. The only reported decisions in point by other state supreme courts have upheld the trustworthiness of such lie-detector induced confessions. ${ }^{268}$ Indeed, contrary to the Sims decision, the Pennsylvania courts hold them admissible even though the test was involuntary, ${ }^{269}$ but Pennsylvania, unlike Illinois, does not follow the federal rules of exclusion of illegally obtained evidence. The Sims holding undoubtedly imposes a limit on the

264 Senate Bill 66, 65 Illinois General Assembly, approved July 2, I947.

${ }^{265} 395$ Ill. 69,69 N.E. 2 d 336 (I946).

${ }^{266} \mathrm{Ibid}$., at 72 and 338 .

${ }^{267}$ People v. Rooney, 355 Ill. 6I3, Igo N.E. 85 (I934); People v. Castree, 3 II Ill. 392, I43 N.E. II2 (I924); People v. Brocamp, 307 III. 448, I38 N.E. 728 (I923).

${ }^{268}$ State v. Dehart, 242 Wis. 562,8 N.W. 2 d 360 (I943); Commonwealth v. Jones, $34 \mathrm{r}$ Pa. 54r, 19 A. 2d 389 (194r); Commonwealth v. Hipple, 333 Pa. 33, 3 A. 2d 353 (r939).

${ }^{269}$ Commonwealth v. Jones, $34 \mathrm{I} \mathrm{Pa.} \mathrm{54I,} \mathrm{I9} \mathrm{A.} \mathrm{2d} 389$ (I94I); Commonwealth v. Hipple, $333 \mathrm{~Pa} .33,3$ A. 2d 353 (1939). 
evidence-gathering techniques employed by Illinois police in connection with use of the lie detector. But the lie detector will probably continue to be used, for although confessions so obtained may be inadmissible, it remains a tool for obtaining clues leading to other kinds of evidence which are admissible. ${ }^{270}$

In another recent case, People v. Kraus, ${ }^{27 x}$ the Court stated that when a confession is attacked as involuntary all persons present when the confession was made must be called as witnesses, if practicable, so that the court may have all the facts surrounding the making of the confession. In this case the absence from the trial of a police captain allegedly present at the making of the confession was not explained by the prosecution. The Court indicated that this unexplained absence would have been grounds for reversal had there not been other competent evidence which left no doubt as to the defendant's guilt. The requirement that all persons in authority present at the confession be in attendance at the trial, or that their absence be satisfactorily explained, appears to be a rule peculiar to Illinois. ${ }^{272}$ Although this requirement may impose a burden on the prosecution, it does not seem unreasonable in view of prevalent third-degree tactics. ${ }^{273}$ The Court's affirmance of the conviction, despite admission of the confession, because guilt was proved to the Court's satisfaction by other competent evidence, is an established Illinois doctrine ${ }^{274}$ which has been adopted by far the greater number of states. ${ }^{275}$

Zaremba v. Skurdialis ${ }^{27}$ indicates that the Illinois Supreme Court is considerably hampered in its rulings on spousal evidence by legislation which is both ambiguous and based on antiquated exclusionary policies. Section 5 of the Evidence Act, ${ }^{277}$ which applies to civil cases, and Section 734 of the Criminal Code $^{28}$ were adopted in 1872 and 1874 respectively.

${ }^{270} 3$ Wigmore, Evidence $\S 999$ (3d ed., I940).

${ }^{27 x} 395$ Ill. 233,69 N.E. $2 d 885$ (I946).

${ }_{72}$ People v. Ickes, 370 Ill. 486, Ig N.E. 2d 373 (I939); People v. Arendarczyk, 367 Ill. 534, I2 N.E. 2d 2 (I937); People v. Cope, 345 Ill. 278 , I78 N.E. 95 (1931). For a tendency in the same direction in other states, see State v. Scarbrough, 167 La. 483, Irg So. 523 (1929) and State v. Lord, 42 N.M. 638,84 P. $2 d 80$ (I938).

273 Keedy, The Third Degree and Legal Interrogation of Suspects, 85 U. of Pa. L. Rev. 76 (1937).

274 People v. Oberholdt, 359 IIl. 39, I93 N.E. 608 (I934); People v. McCurrie, 337 Ill. 29o, I69 N.E. 214 (I929); People v. Michael, 280 Ill. Ir, II 7 N.E. I93 (I9I 7); People v. Cleminson, 250 Ill. I35, 95 N.E. I 57 (I9II).

275 I Wigmore, Evidence $\S 21$ (3d ed., 1940).

${ }^{276} 395$ Ill. 437,70 N.E. 2d 6 I7 (1946).

${ }_{277}$ IIl. Rev. Stat. (I945) C. 5I, $\& 5$. ${ }_{278}$ Ill. Rev. Stat. (1945) c. $38, \S 734$. 
This legislation, codifying a number of obsolete common law rules, was amended reluctantly and only after serious criticism by the Court ${ }^{279}$ and text writers. ${ }^{280}$ Section 5 was described forty-one years ago by Wigmore in the following language: "The whole of it is a patchwork of thirty years' growth, and is full of inconsistencies which make it unique of its kind in American legislation." ${ }^{28 x}$ The section to which this authoritative exception was taken in r 906 was not amended by the Illinois legislature until I935. ${ }^{282}$ The criminal statute was amended two years later. ${ }^{283}$ The complete spousal incompetency of the early common law is removed in both amendments, but much is left to be desired in the proviso which disqualifies the husband or wife in matters related to "any communication or admission .... or any conversation ... . during coverture." Such language has in some jurisdictions not only been construed to give the sender of the communication a privilege, but has been held to confine the privilege to confidential communications. ${ }^{284}$ The Illinois Court, however, seems to construe the language of the proviso not only to mean incompetency rather than privilege, but also to cover not only confidential communications, but any communication. ${ }^{285}$ Thus, when the defendant in the Zaremba case offered testimony of the plaintiff's divorced wife, stating that she would not "testify concerning matters touching on the confidential relationship between husband and wife excluded by the statute," ${ }^{286}$ the trial court held the witness incompetent, and excluded the testimony. The Supreme Court reversed and remanded, but failed to define the possible area of testimony which does not "touch on the confidential relationship of husband and wife" and which may be admissible. Although some decisions of the Court may indicate that all communications, whether or not they are confidential, are inadmissible, ${ }^{287}$ the uncertainties regarding the statute, coupled with the reversal in the instant case, would seem to call for an opinion clearly delineating the scope of the statute. A desirable solution

279 People v. Kendall, 357 Ill. 448, I92 N.E. 378 (1934).

${ }^{280}$ Wigmore, Some Evidence Statutes That Illinois Ought to Have, r Ill. L. Rev. 9 (Ig06); 2 Wigmore, Evidence $\delta \S 609,6$ Io (3d ed., I940).

${ }^{28 x}$ Wigmore, Some Evidence Statutes That Illinois Ought to Have, I Ill. L. Rev. 9, I4 (1906).

${ }^{282}$ Ill. Rev. Stat. (I945) c. 5I, $\$ 5$.

${ }_{283}$ Ill. Rev. Stat. (I945) c. $38, \$ 734$.

${ }^{28} 4$ New York Life Ins. Co. v. Mason, 272 Fed. 28 (C.C.A. gth, I921); Sexton v. Sexton, 129 Iowa 487, I05 N.W. $3 I_{4}$ (1905); Commonwealth v. Sapp, 90 Ky. 580, 44 S.W. 834 (I890).

${ }^{285}$ Dunn v. Heasley, 375 Ill. 43 , 30 N.E. $2 d 628$ (1940); Heineman v. Herman, 385 Ill. rgr, 52 N.E. 2d 263 (1943); Note, Evidence, Disability of Husband and Wife in Illinois, 30 Ill. L. Rev. 783 (I936).

$$
{ }^{286} 395 \text { IIl. 437, 438, } 70 \text { N.E. 2d 6r7, 6I8 (1946). } \quad{ }^{287} \text { Note } 285 \text { supra. }
$$


to the problem is embodied in an amendment proposed by the Chicago Bar Association when the I935 amendment was adopted. This suggested wording, after abolishing the incompetency of husband and wife, provided that "neither [spouse] shall, without the consent of the other during marriage or afterwards, be permitted to testify to private communications. ${ }^{3288}$ Such a statute would protect the privilege only for confidential communications, which modern writers seem to agree is the only exclusionary rule pertaining to spousal testimony which the courts or legislatures are justified in retaining. ${ }^{289}$

One of the most firmly entrenched doctrines of the Illinois Supreme Court is that excluding opinion evidence on an ultimate issue of fact. ${ }^{290}$ Gillette v. Chicago ${ }^{295}$ was a suit to recover expenses incurred by the plaintiff in shoring its building to protect it from settling of the soil caused by city subway construction. The city appealed from an adverse judgment, assigning as error failure to admit testimony of an expert witness. After he had testified on various technical points, the expert was asked the following question: "Have you an opinion, based upon your knowledge of the type of construction of the subway .... whether shoring or underpinning measures were necessary during the construction of the subway?" Refusal of the trial court to admit an answer was upheld by the Supreme Court on the ground that the subject was inappropriate for expert testimony since it constituted the ultimate issue before the jury. Quite apart from its coincidence with the ultimate issue, the question seems improper because it did not make clear what facts concerning the construction of the subway and of the building were known to the expert. The Illinois Court, however, has long held that the admission of expert opinion on an ultimate issue of fact would "usurp the province of the jury." ${ }^{292}$ Why the jury may not have the help of an expert on the very point upon which it is incapable itself of making an intelligible determination is difficult to understand. Further, most observers agree that the "province of the jury" cannot be "usurped," since the jury may still reject the expert's opinion and accept some other view, "and no legal power, not even the judge's order, can compel them to accept the witness's

${ }^{288}$ McCormick, Notes and Suggestions on the Evidence Act of Illinois, 3 Univ. Chi. L. Rev. 465,467 (1936).

${ }^{289}$ Hutchins and Slesinger, Some Observations on the Law of Evidence-Family Relations, $x_{3}$ Minn. L. Rev. 675 (1929); Evidence, Disability of Husband and Wife in Illinois, 30 Ill. L. Rev. 783 (1936).

${ }^{29 \circ}$ King and Pillinger, Opinion Evidence in Illinois 8-9 (1942).

${ }^{295} 396$ Ill. 6I9, 72 N.E. 2d 326 (I947).

${ }_{292}$ Chicago \& Alton R. Co. v. Springfield \& Northwestern R. Co., 67 Ill. I42 (1873). 
opinion against their own."1293 In the federal courts and in many state courts the judge himself is permitted to express his opinion on the weight of the evidence, and the cases are legion in which the jury has taken a different position from that taken by the trial judge. ${ }^{294}$

In view of the strong line of precedent in Illinois, adverse criticism of the result in the Gillette case must be tempered, but one may well question the Court's failure to question such precedent or to suggest legislative action. A ready model for the legislature is at hand in Section 9 of the Uniform Expert Testimony Act, ${ }^{295}$ which admits opinion evidence on issues like the disputed one in the Gillette case, leaving the opponent to crossexamination to test the underlying facts upon which the expert has formed his opinion. Adoption of such a statute would not only bring this area of Illinois evidence law into agreement with "the modern tendency to make no distinction between evidential and ultimate facts subject to expert opinion" ${ }_{296}$ but would eliminate many of the recurrent difficulties raised by the hypothetical question.

\section{THE COURT}

The analysis of some of the cases in the preceding sections gives some indication of why the Court decides cases as it does. The Court's techniques of statutory construction, its attitude toward the state constitution, toward local government bodies, and toward administrative agencies, its use of precedent, and the extent of its concern with the social implications of its decisions have each been pointed to as influencing the result of one or another of the cases. In this section an attempt is made to examine the Court as a social institution and to determine the influence on its decisions of such factors as the quantity of its work, its method of preparing opinions, and the kinds of cases which appear on its docket.

A recurrent problem with the Illinois Supreme Court has been keeping abreast of its business. Its inability to keep up with the flow of appeals resulted in the enlargement of the Court from three to seven justices in 1870 , in the creation of intermediate appellate courts in 1877 , in the certiorari act of 1909 , and in the addition of commissioners to assist the Court in r927. At present, however, the Court is keeping up with its work, so that cases are decided in the term after they are docketed. ${ }^{297}$ Indeed,

2937 Wigmore, Evidence \& I920 (3d ed., I940).

$294 \mathrm{Ladd}$, Review of King and Pillinger, Opinion Evidence in Illinois, 29 A.B.A.J. I44 (r943).

295 Uniform Model Expert Testimony Act, \& 9, U.L.A. (Supp., I946).

${ }^{296}$ State v. Cox, 172 Minn. 226, 230, 215 N.W. 189, rgI (1927).

297 Table 2, infra, at 165 , describes the work of the Court during the last year. 
at no term last year was the Court obliged to carry the call of the civil docket over into a third week. The number of opinions written, 248 last year, has declined substantially from a peak in the twenties and has continued to decline slightly in recent years. ${ }^{298}$ During the years I900 to Igro the Court handed down about 500 opinions a year, ${ }^{299}$ and from IgIo to rgrg an annual average of 388 opinions. ${ }^{300}$ In I923 Mr. Justice Thompson indicated that the Court was writing 525 opinions a year, ${ }^{30 x}$ and in 1936 Mr. Justice Orr found an over-all average of 285 opinions a year. ${ }^{302}$ The members of the Illinois Supreme Court still bear a heavier burden of opinion writing than do the judges of most states, but that burden is considerably lighter than that of the judges in Michigan and New York. ${ }^{303 .}$ However, should the present high level of business activity generate a large volume of cases for the highest state courts as it did in the twenties, overcrowded dockets will again become a disturbing factor. ${ }^{304}$ Moreover, if there should be an increase in the number of cases argued orally, if the number of dissenting opinions should increase, or if the business of the Court should include more important cases, there would be insufficient time to hear even the number of cases decided this year. Furthermore, if new duties were added, such as those suggested by the Chicago Bar Association, ${ }^{305}$ the situation would become even more serious.

The Tllinois Supreme Court is not continuously in session, but meets in Springfield for five terms each year, commencing on the second Mondays of September, November, January, March, and May. During I946-47, for example, the Court sat only during two weeks each term or a total of

${ }^{298}$ See Table 3, infra, at 166.

299 A Statistical Review of the Work of the Supreme Court of Illinois for Ten Years I 900 to I9IO, at I53 (IgI2), deducting the number of cases dismissed on motion and cases of supersedeas and certiorari denied from the total of cases filed.

${ }^{300}$ Legislative Reference Bureau of Illinois, Constitutional Convention Bulletin No. ro, at 896 Table 8 (Ig20).

30r Report of the Illinois State Bar Association 457, 463 (I923).

${ }^{302}$ Orr, the Supreme Court of Illinois, 24 IIl. B. J. 297 (I936); see Clarke, Supreme Court Cases Increase, 25 Chicago Bar Record 222 (I944).

${ }^{303}$ Statistics on the volume of work handled by the highest state courts are available in the annual reports of the Judicial Councils of California, Connecticut, Kansas, Massachusetts, Michigan, Minnesota, New York, Texas, and Washington, and in the following law reviews for their respective states: I4 Rocky MLt. L. Rev. 213 (I942)(Colorado); 7 La. L. Rev. 165 (1947); 8 Md. L. Rev. 9I, II2 (I944); I5 Miss. L. J. 66 (1942); II Mo. L. Rev. 345 (1946); I947 Wis. L. Rev. 39 .

${ }^{304}$ Statistics on long term trends in other states are available in the reports of the Judicial Councils of Connecticut, Kansas, Massachusetts, Michigan, and Minnesota, and in 7 La.L. Rev. 165 (1947) and in 1947 Wis. L. Rev. 39.

${ }_{305}$ Witwer, The Illinois Constitution and the Courts, I5 Univ. Chi. L. Rev. 53 (1947). 
TABLE 2*

THE WORK OF THE ILLINOIS SUPREME COURT DURING THE TERMS SEPTEMBER, I946 TO MAY, I947

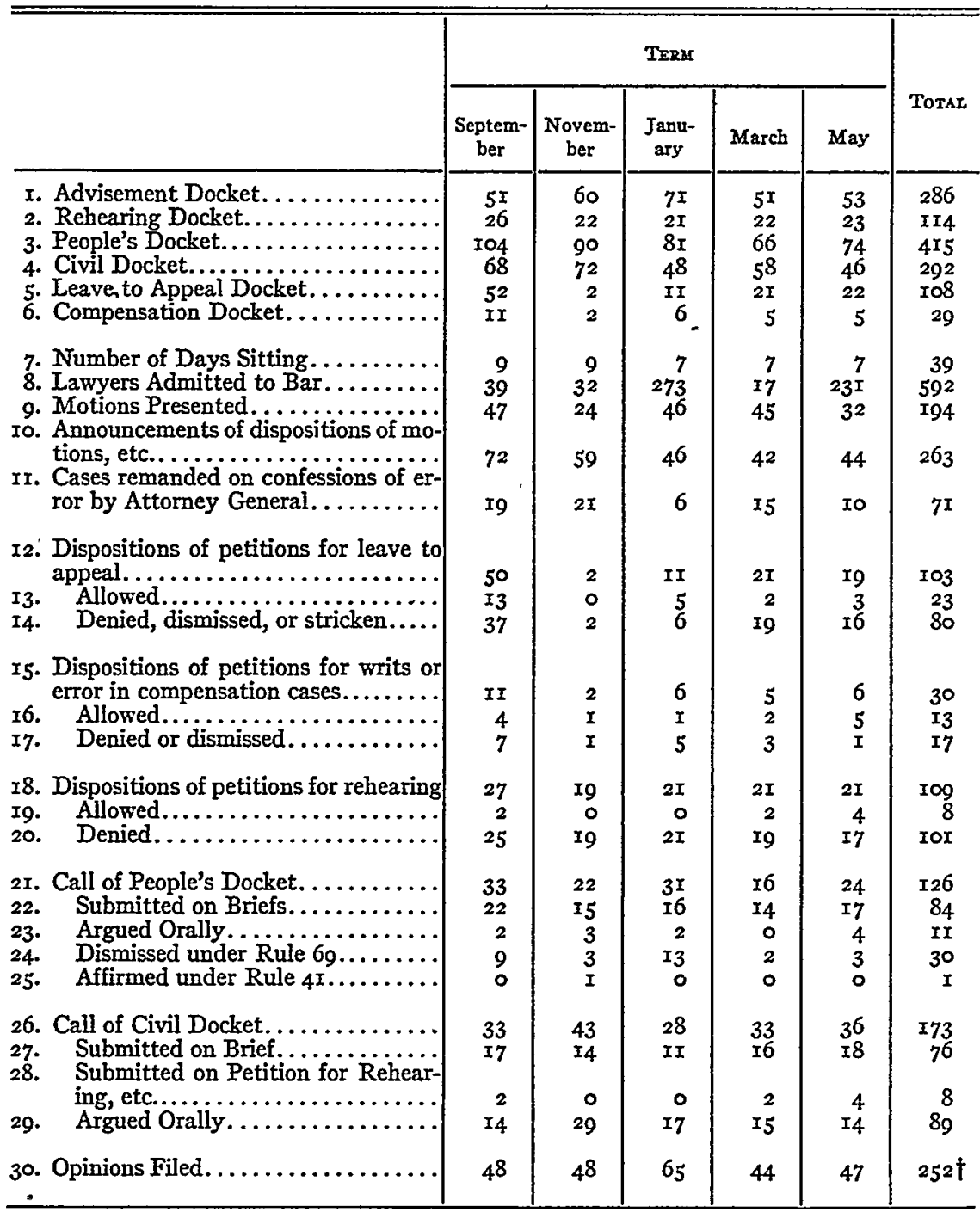

* Sources: Lines I-6, the printed dockets prepared by the clerk of the Illinois Supreme Court; Lines I2-17, the tables in 393 Ill. 629, 394 Ill. 629, 395 Ill. 627, 397 Ill. I09; all other lines, the Chicago Daily Law Bulletin.

t This figure from the Chicago Daily Law Bulletin on number of opinions filed can perhaps be reconciled with a count of oplinions published in the reports with filing dates during the last five terms by deducting opinions filed and withdrawn when rehearings were granted. 
thirty-nine days. Cases are assigned to the judges for opinions in the order in which the cases appear on the docket, so that each judge is assigned every seventh case. This method of mechanical assignment, which disregards the abilities and interests of the respective judges, has been defended on the grounds that individual assignment by the chief justice cannot avoid feelings of favoritism, that each judge is induced to put forth his best efforts to keep abreast on his share of the work, and that the judges never come to rely upon the learning of any judge as a specialist in a particular type of case. ${ }^{306}$

If the case has been submitted on briefs, the judge to whom it is assigned generally writes his opinion without any formal discussion of the

TABLE $3^{*}$

THE VOLUME OF WORK IN THE ILLINOIS SUPREME COURT

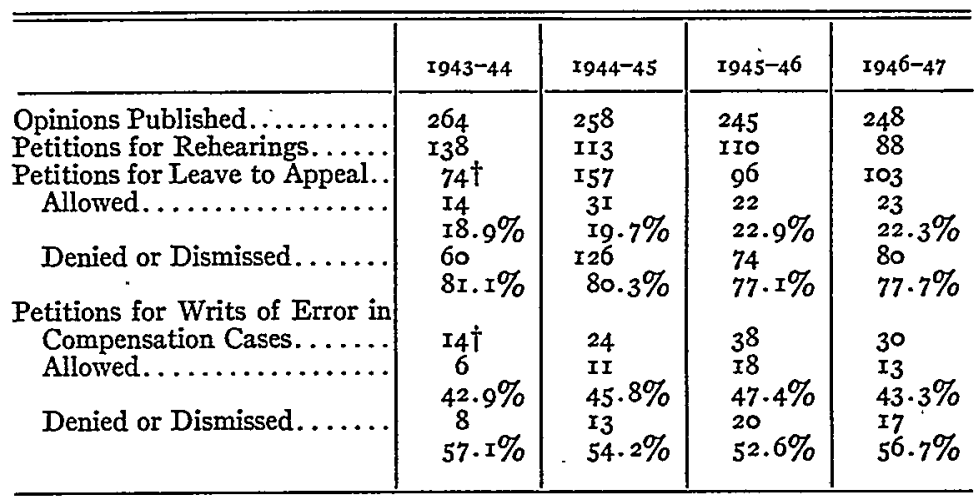

* Source: The published reports of the Court.

† January, March, and May terms only. The Reporter did not begin to publish a table of cases on the Leave to Appeal and Compensation Dockets until January 1944.

case with his colleagues. A conference on the case before the judges separate at the end of each term is almost precluded, since the rules of the Court do not require the filing of the appellee's brief before the first day of the term and of the appellant's reply brief before the second Monday of the term. During the crowded term days the Court probably has no time for preliminary conferences on newly submitted cases. A short postponement of adjournment after all cases have been submitted conceivably would

${ }^{306} \mathrm{Mr}$. Floyd Thompson, a former justice of the Illinois Supreme Court, twenty years ago gave an excellent account of how the Court handled its work. Report of the Illinois State Bar Association 457 (1923), reprinted in 1o Chicago Bar Ass'n Rec. 97 (1926) and in Dodd and Edmunds, Illinois Appellate Procedure \$ 15 (1929). See also Carter, Methods of Work in Courts of Review, I2 Ill. L. Rev. 231, 25I (I9I7); Hiscock, The Court of Appeals of New York; Some Features of Its Organization and Work, I4 Cornell L. Q. I3I, I38 (I929); but cf. Hughes. The Supreme Court of the United States 59 (1928). 
provide time for conferences, but would still permit only a cursory examination of the briefs and abstracts. If the case is argued orally, the judges hold a short conference after the day's arguments and take an "impression vote" on the preliminary reaction to the oral argument. The vote is neither final nor binding on the judge writing the opinion. This indicates a difference, however, between a case submitted on oral argument and a case submitted on briefs. Only in the former has the judge assigned to write the opinion had any prior conference with or expression of opinion from his colleagues. ${ }^{307}$

Between terms each judge takes the record and two copies of the briefs and abstract in cases assigned to him during thepreceding term to his office to write his respective opinions. Upon completion, the manuscripts are sent to the official reporter, who prints the opinion and mails a galley proof to each of the justices. Thus, at the end of the vacation each justice has copies of the opinions of the other justices and can review them in conjunction with the briefs and abstracts of the cases in preparation for conferences. At the beginning of the next term, conferences are held on the opinions submitted, and the opinions, if approved, are filed. Petitions for rehearing, however, are submitted in almost half the cases, and the corresponding opinions.are not published, but are placed upon a Rehearing Docket and reconsidered at the next term. Minor changes are often made on the basis of the petitions for rehearing; occasionally an additional per curiam opinion is filed; and in a surprisingly large proportion of cases the petition for rehearing is granted and the case is put on the docket a second time. ${ }^{308}$

This method of writing opinions has some tendency to make the opinions and the decisions of the Court one-judge affairs. ${ }^{309}$ In those cases not argued orally (a majority), the judge to whom the case is assigned reaches a decision and writes the opinion without any preliminary conference with his colleagues; in those argued orally, the judge has only a non-definitive "impression vote" to guide him. The judges, therefore, instead of discussing the case together on equal terms, begin the discussion on the basis of a prepared, complete opinion of a colleague. A judge reading a complete opinion will probably be more reluctant to disagree and less likely to suggest and explore difficulties that come to his mind than if the case were be(1947).

${ }^{307}$ Compare Lardner, Thoughts on the Supreme Court of Illinois, 42 Ill. L. Rev. 53, 63

${ }^{308}$ See Table 2.

${ }^{309}$ For other comments on the Court's method of reaching decision and writing opinions see Lardner, Thoughts on the Supreme Court of Illinois, 42 Ill. L. Rev. 53 (I947). 
ing discussed before an opinion had been prepared. The lack of prior conferences is thus perhaps reflected in the small number of dissents and concurrences. The Court has generally been in agreement; indeed, the proportion of cases in which the Court split declined from I7.5 per cent in I935-36 to 5.5 per cent last year. ${ }^{300}$ Most of the few dissents and concurrences were without opinions, for a dissenting justice must either crowd the writing of a dissent into already full term days or add the dissenting opinion to the list of opinions he must prepare for the next term. The value of special concurrences and dissenting opinions in clarifying issues and introducing new ideas into the law has been demonstrated by the experience of the United States Supreme Court. And the effect of written dissents in bringing about important changes in the law is also well known.

Another result of the burden of preparing written dissents and special concurrences may be the small number of cases in which a conscious attempt is made to shape the law. One might speculate that when a written opinion is presented in final form to a busy Court the natural tendency is to eliminate unnecessary controversial matter that might evoke dissents. Whether this factor, or the kind of cases the Court hears, or the lack of an intermediate appellate court in so many cases, is most responsible for the uninteresting character of the Mlinois advance sheets is impossible to determine.

A potentially greater danger of the lack of preliminary conferences is that the outcome of the case may depend on the judge assigned to write the opinion. However, a study of last year's opinions, and of dissents and concurrences for several preceding years, showed no case in which it could be asserted that if it had been assigned to another judge the result would have been different. Neither did this study show any definite differences in viewpoints among the justices, so that the inability to find evidence of the influence of individual views on the decisions may result from the general similarity of their views. However, a more comprehensive study of several years' cases might have yielded more conclusive results.

The great majority of cases coming to the Court-almost 75 per centarrive there by means of various rights of direct appeal. ${ }^{\text {trI }}$ As already indicated, under the Constitution an appeal of right may be taken to the Supreme Court "in all criminal cases, and cases in which a franchise, or a freehold, or the validity of a statute is involved." By statute, all these cases (except criminal cases "below the grade of felony") go to the Su-

${ }^{30}$ In a recent year the United States. Supreme Court split in 58 per cent of its opinions, Pritchett, Thè Divided Supreme Court, I944-I945, 44 Mich. L. Rev. 427 (I945).

3ז See Table 4. 
preme Court directly. Such cases constitute over half the cases decided by the Court. In addition, under Section 75 of the Civil Practice Act all cases in which "a construction of the constitution is involved" and cases in which "the validity of a municipal ordinance is involved and in which the trial judge shall certify that in his opinion the public interest so requires, and in all cases relating to revenue, or in which the State is interested as a party or otherwise" may be appealed directly to the Supreme Court. These cases constitute about 12 per cent of the number decided by the Court. Further, a direct appeal lies under various special statutes, the most important of which are listed in Table 4. These statutes give rise to 3-9 per cent of the cases decided by the Court.

The Court itself grants permission for review in Io-I6 per cent of its cases. Such permissive review includes petitions for leave to appeal from appellate courts and petitions for writs of error in compensation cases. It should be noted that the Court has much more readily granted permissive review in compensation cases, granting over 40 per cent of the petitions, than it has in petitions for leave to appeal, only 20 per cent of which have been granted. ${ }^{312}$ This difference may be traceable to a belief that compensation cases coming directly from the circuit courts require stricter review than do cases coming from intermediate appellate courts where they have already had one appellate review.

The original jurisdiction of the Supreme Court is defined by the Constitution to lie "in cases relating to the revenue, in mandamus, and habeas corpus." Last year this jurisdiction was invoked in three mandamus cases to compel action by lower court judges, and in four habeas corpus cases on behalf of criminal prisoners. The number of original actions decided by opinion has varied over the years from 3 to 5 per cent of the total. Cases coming up on certificates of importance granted by the appellate courts furnish only 2 or 3 per cent of the Court's business; and cases coming up by appeal of right from the appellate courts furnish another 2 or 3 per cent of the Court's business.

It should be noted that over 75 per cent of the cases come directly from the trial courts, either by direct appeal of right or by permissive writs of error in compensation cases, and only II to $I 7$ per cent come from intermediate appellate courts. These figures indicate that in 80 to $9 \circ$ per cent of its cases the Supreme Court is either the first court or the first appellate step and, therefore, takes the issues without the preliminary sifting and pointing up which might occur during an appellate court appeal. Thus in

${ }^{32}$ See Tables 2 and 3. 
many cases the Court is merely applying well-established rules of law to given facts, rather than deciding new points of law.

In almost 80 per cent of the cases, the decision as to whether or not the Supreme Court will review is made by the litigants themselves by taking advantage of the Court's original jurisdiction, by direct appeal of right, or by an appeal of right from the appellate courts. In about 3 per cent of the cases the trial court makes the decision through its power to determine

TABLE $4^{*}$

OPINIONS ANALYZED BY SOURCE OF AUTHORITY TO REVIEW

\begin{tabular}{|c|c|c|c|c|c|c|}
\hline & $\begin{array}{c}\text { I935- } \\
36\end{array}$ & $\begin{array}{l}1939- \\
40\end{array}$ & $\begin{array}{l}2943^{-} \\
44^{-}\end{array}$ & $\begin{array}{c}1944^{-} \\
45\end{array}$ & $\begin{array}{l}1945^{-} \\
46\end{array}$ & $\begin{array}{l}946- \\
47\end{array}$ \\
\hline Origi & $\begin{array}{l}\text { Io } \\
3.9 \%\end{array}$ & $\begin{array}{l}7 \\
3.1 \%\end{array}$ & $\begin{array}{r}34 \\
5.3 \%\end{array}$ & $\begin{array}{l}8 \\
3.1 \%\end{array}$ & $\stackrel{\text { I3 }}{5 \cdot 3 \%}$ & $\begin{array}{l}8 \\
3.2 \%\end{array}$ \\
\hline $\begin{array}{r}\text { Direct } R \\
\text { Crimin }\end{array}$ & & & & & & \\
\hline Freeh & $\begin{array}{l}32.3 \% \\
40\end{array}$ & $\begin{array}{l}12.9 \% \\
58\end{array}$ & $\begin{array}{l}21.2 \% \\
55\end{array}$ & $23.3 \%$ & $34 \cdot 3 \%$ & $\begin{array}{l}32.7 \% \\
58\end{array}$ \\
\hline Constitutional Questions... & $\begin{array}{l}15.6 \% \\
29\end{array}$ & $\begin{array}{l}25.8 \% \\
25\end{array}$ & $20.8 \%$ & $2 \mathrm{I} \cdot 3 \%$ & $20.8 \%$ & $23.4^{\circ}$ \\
\hline Franchise & $\begin{array}{c}\text { II. } 3 \% \\
2\end{array}$ & & II. $4 \%$ & $6.2 \%$ & $6.9 \%$ & $7.3 \%$ \\
\hline Validity of Municipal Ordinan & 8 & $9.4 \%$ & I. $1 \%$ & $6.9 \%$ & $.8 \%$ & $\begin{array}{l}3 \\
6.2\end{array}$ \\
\hline Reve & 19 & $\begin{array}{l}32 \\
14.2 \%\end{array}$ & $24.1 \%$ & $\begin{array}{l}26 \\
10.1 \%\end{array}$ & $\begin{array}{r}2 \mathrm{I} \\
8.6 \%\end{array}$ & $\begin{array}{l}2.4 \% \\
25 \\
10.1 \%\end{array}$ \\
\hline State & $\begin{array}{l}5 \\
1.0 \%\end{array}$ & $2.0 \%$ & ….... & $I .4 \%$ & $\cdots$ & ........ \\
\hline e Commission. & 70 & $\begin{array}{l}3 \\
\mathrm{I} .3 \%\end{array}$ & $\begin{array}{ll}x & \\
& .4 \%\end{array}$ & $\begin{array}{l}4 \\
\text { I. } 6 \%\end{array}$ & $\cdots$ & $\begin{array}{l}4 \\
\text { I. } 6^{\circ}\end{array}$ \\
\hline Ele & & $4.8 \%$ & $50 \%$ & ......... & I,$\%$ & $\ldots$ \\
\hline Unemployment Compensation Ac & $\ldots$ & ....... & & & & \\
\hline Emine & $\begin{array}{l}4 \\
\text { I. } 6 \%\end{array}$ & $\begin{array}{l}3 \\
x .3 \%\end{array}$ & $\begin{array}{l}4 \\
x .5 \%\end{array}$ & ${ }^{2} .8 \%$ & $2.8 \%$ & 3 \\
\hline Other Spe & & $3.3 \%$ & $2.8 \%$ & $5.0 \%$ & $2.8 \%$ & ${ }^{2} 80$ \\
\hline $\begin{array}{l}\text { Review by Permission of the Supreme } \\
\text { Court: } \\
\text { Leave to Appeal................. }\end{array}$ & ${ }^{17} 6.6 \%$ & $\begin{array}{l}25 \\
11.1 \%\end{array}$ & $\begin{array}{l}3 \mathrm{I} \\
\mathrm{II} .8 \%\end{array}$ & $\begin{array}{l}28 \\
10.9 \%\end{array}$ & $\begin{array}{l}\text { I9 } \\
7.8 \%\end{array}$ & $\frac{18}{7.3 \%}$ \\
\hline $\begin{array}{l}\text { Workmen's Compensation Writs of Er- } \\
\text { ror.............................. }\end{array}$ & $\begin{array}{l}\text { II } \\
4.3 \%\end{array}$ & $\begin{array}{l}12 \\
5 \cdot 3 \%\end{array}$ & $\begin{array}{c}\text { I3 } \\
4.9 \%\end{array}$ & $\begin{array}{l}9 \\
3 \cdot 5 \%\end{array}$ & $\begin{array}{l}15 \\
6.1 \%\end{array}$ & ${ }^{13} .2 \%$ \\
\hline Review by Certificate of Importanc & 6 & 5,0 & 9 & 5 & & \\
\hline $\begin{array}{l}\text { Review of Right from the Appellate } \\
\text { Courts: } \\
\text { Criminal Cases................. }\end{array}$ & $2 \cdot 3$ & & 3.470 & & & \\
\hline & $3.5 \%$ & $2.2 \%$ & I. $1 \%$ & $2.7 \%$ & $\stackrel{4}{1} .6 \%$ & $\begin{array}{l}4 \\
\text { I. } 6 \%\end{array}$ \\
\hline & & ${ }^{2} .9 \%$ & ${ }^{2} .8 \%$ & $\frac{4}{x} .6 \%$ & I $.4 \%$ & …. \\
\hline
\end{tabular}

* Source: The published reports of the Court. 
that the validity of a municipal ordinance raises questions of public importance. In 2 to 3 per cent of the cases the appellate court makes the decision through granting a certificate of importance. In only io to I5 per cent of the cases does the Court itself make the decision by granting leave to appeal or writs of error in compensation cases. As a result, the Supreme Court has very little control over the number and nature of cases which it decides. Moreover, the Illinois legislature itself has only partial control, because more than half the cases reach the Court on grounds enumerated in the Constitution. The legislature can require that such litigation pass through an intermediate appellate review, but it cannot prevent an ultimate appeal to the highest court. Yet the Court might,

TABLE $5^{*}$

LEGAL RELATIONS GIVING RISE To LITIGation REACHING THE SUPREME COURT

\begin{tabular}{|c|c|c|c|c|c|c|}
\hline & $\begin{array}{l}1935^{-} \\
36\end{array}$ & $\begin{array}{c}1939^{-} \\
40\end{array}$ & $\begin{array}{c}1943- \\
44\end{array}$ & $\begin{array}{l}1944^{-} \\
45\end{array}$ & $\begin{array}{l}1945^{-} \\
46\end{array}$ & $\begin{array}{c}x 946- \\
47\end{array}$ \\
\hline Procedure and Evidence. & $\cdots \cdots$ & & & & & \\
\hline $\begin{array}{l}\text { Public Law: } \\
\text { Constitutional Problems......... }\end{array}$ & & 3 & & & $\cdots$ & 3 \\
\hline Local Government Bodies. . . . . . . . . & 12 & $19 . \%$ & 18 $6.8 \%$ & I8 & $18 \%$ & I9 $7.7 \%$ \\
\hline State Officials.............. & II $4.3 \%$ & $5.2 \%$ & $6.3 \%$ & & $.8 \%$ & $2.0 \%$ \\
\hline Eminent Domain. & $5.9 \%$ & & & & $3.2 \%$ & I. $6 \%$ \\
\hline 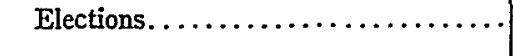 & $6.3 \%$ & $4.8 \%$ & $5.9 \%$ & $\ldots \ldots$ & $.4 \%$ & $.4 \%$ \\
\hline Unemployment Compensation... & $\ldots \ldots$ & $\ldots \ldots$ & $4.2 \%$ & I7 $6.6 \%$ & $.8 \%$ & .8 \\
\hline Taxation. . . . . . . . . . . . . & $\stackrel{22}{8.6 \%}$ & $\begin{array}{l}42 \\
18.7 \%\end{array}$ & 34 & $\begin{array}{l}33 \\
\text { I2. } \\
\end{array}$ & $\begin{array}{r}24 \\
9.8 \%\end{array}$ & $25.1 \%$ \\
\hline Business Law. . . . . . . . . . & $9 \cdot 3 \%$ & $8.0 \%$ & I7 $6.4 \%$ & $\begin{array}{l}\text { Ig } \\
7.4 \%\end{array}$ & I0 $.1 \%$ & $4.6 \%$ \\
\hline Personal Relations: & & & & & & \\
\hline Torts.......... & $\frac{9}{3.5 \%}$ & $\begin{array}{l}7 \\
3 . I \%\end{array}$ & ${ }^{I 7} 6.4 \%$ & $\begin{array}{l}5 \\
1.9 \%\end{array}$ & $\begin{array}{l}8 \\
3 \cdot 3 \%\end{array}$ & $2.8 \%$ \\
\hline Workmen's Compensation. & $12 \%$ & $12.3 \%$ & I3 $4.0 \%$ & $9.5 \%$ & I6 $6.5 \%$ & 13 \\
\hline Domestic Relations. & $\begin{array}{c}10 \\
3.9 \%\end{array}$ & $8.5 \%$ & $\frac{5}{5} .9 \%$ & $5.9 \%$ & $8.3 \%$ & $2.0 \%$ \\
\hline Property: & & & & & & \\
\hline Real & $\begin{array}{l}27 \\
10.5 \%\end{array}$ & $\begin{array}{l}37 \\
16.4 \%\end{array}$ & $\begin{array}{l}4^{2} \\
\mathbf{I}_{5} .9 \%\end{array}$ & $\begin{array}{l}44 \\
17.1 \%\end{array}$ & $\begin{array}{l}3^{8} \\
{ }_{5} 5.5 \%\end{array}$ & $\begin{array}{l}34 \\
13.7 \%\end{array}$ \\
\hline Trusts....... & $\begin{array}{l}4 \\
\mathrm{I} .6 \%\end{array}$ & $\begin{array}{l}5 \\
2.2 \%\end{array}$ & $\begin{array}{l}3 \\
1.1 \%\end{array}$ & $\begin{array}{l}5 \\
1.9 \%\end{array}$ & $\begin{array}{l}3 \\
\text { I. } 2 \%\end{array}$ & $3.2 \%$ \\
\hline Wills and Probate. . & $\begin{array}{l}\text { Io } \\
3.9 \%\end{array}$ & $\stackrel{15}{6.7 \%}$ & $\begin{array}{l}\mathrm{r}_{4} \\
5.3 \%\end{array}$ & $\stackrel{15}{5.8 \%}$ & $\stackrel{\mathrm{I}_{3}}{5.3 \%}$ & $\begin{array}{l}\text { I8 } \\
7.3 \%\end{array}$ \\
\hline $\begin{array}{r}\text { Criminal Law (including contempt and } \\
\text { disbarment) } \ldots \ldots \ldots \ldots \ldots \ldots \ldots\end{array}$ & $\begin{array}{l}\operatorname{Io5} \\
40.9 \%\end{array}$ & $\begin{array}{l}40 \\
17.8 \%\end{array}$ & $\begin{array}{l}72 \\
27.3 \%\end{array}$ & $\frac{74}{28} .6 \%$ & $\begin{array}{l}98 \\
40.0 \%\end{array}$ & $\begin{array}{l}94 \\
37.9 \%\end{array}$ \\
\hline
\end{tabular}

* Source: The published reports of the Court. 
by further restricting its construction of the terms defining the grounds for appeal, and by requiring strict adherence to procedural prerequisites, decrease the number of such cases reaching it.

As has already been indicated, a remarkably small number of cases in business law, torts, domestic relations, and property matters not involving title are decided each year. The fact that the Court is occupied with so many cases reaching it on grounds enumerated in the Constitution and the Civil Practice Act is probably responsible for the small numbers of

TABLE $6^{*}$

LEGAL RELATIONS GIVING RISE TO LITIGATION REACHING THE APPELLATE COURTS, 1946-47

\begin{tabular}{|c|c|c|c|c|}
\hline & \multicolumn{2}{|c|}{ Fute OpINIONS } & \multicolumn{2}{|c|}{ ABstract OpDToNs } \\
\hline & No. & Per Cent & No. & Per Cent \\
\hline 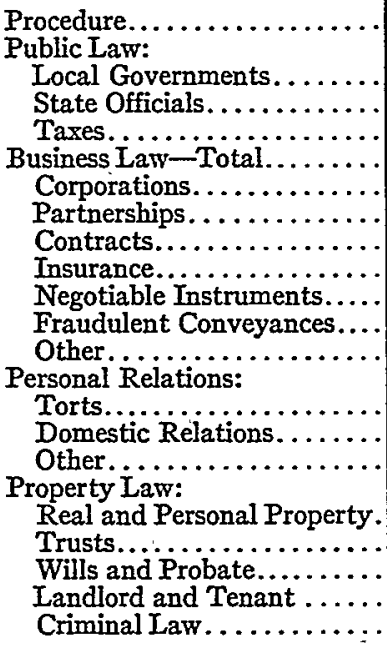 & $\begin{array}{r}7 \\
\ldots . \\
2 \\
40 \\
4 \\
1 \\
16 \\
12 \\
2 \\
2 \\
3 \\
45 \\
12 \\
2 \\
12 \\
2 \\
8 \\
21 \\
9\end{array}$ & $\begin{array}{r}3.6 \\
4.2 \\
\ldots \ldots \ldots \\
1.2 \\
24.1 \\
2.4 \\
.6 \\
9.6 \\
7.2 \\
1.2 \\
1.2 \\
1.8 \\
\\
27.1 \\
7.2 \\
1.2 \\
7.2 \\
7.2 \\
4.8 \\
12.7 \\
5.4\end{array}$ & 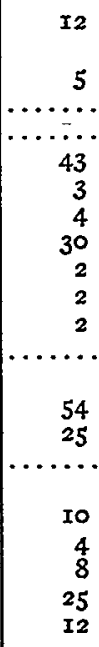 & $\begin{array}{r}6.1 \\
2.5 \\
\ldots \ldots \ldots \\
\ldots \ldots \ldots \\
21.7 \\
1.5 \\
2.0 \\
15.2 \\
1.0 \\
1.0 \\
1.0 \\
\ldots \ldots \ldots \\
\\
27.3 \\
12.6 \\
\ldots \ldots \ldots \\
\\
5.0 \\
2.0 \\
4.0 \\
12.6 \\
6.1\end{array}$ \\
\hline
\end{tabular}

* Source: The published advance sheet reports of the Appellate Courts, September 1946 through July 15,1947 .

cases in other categories heard each year. Table 5 indicates the types of legal relations which give rise to litigation considered by the Court. It does not indicate the field of law involved in the appeal, and no case is classified under procedure and evidence or constitutional problems unless it could not properly be placed elsewhere. Thus, for example, a tort case is classified under torts even though the only fields of law discussed on appeal were procedure and evidence.

To emphasize the division of the fields of appellate litigation between the Supreme Court and the six appellate courts, Table 6 sets forth a simi- 
lar classification of cases in the latter courts during I946-47. Comparison is complicated by the fact that more than half of the appellate court cases are reported only by memorandum decisions indicating the legal problems raised, but not necessarily the facts which produced the litigation. This analysis indicates that the activities giving rise to most of the appellate court cases are business, torts, landlord and tenant, and domestic relations.

Finally, the much discussed underrepresentation of Chicago on the Court is substantiated by the fact that approximately half of the cases originate in Cook County, whereas only one of the seven justices is elected from that area. ${ }^{3 \times 3}$

\section{CONCLUSION}

This study has revealed serious inadequacies in the work of the Illinois Supreme Court. Although the major responsibility for these shortcomings lies with the Illinois Constitution and the Civil Practice Act, the responsibility for the method of assigning cases for opinion writing and the lack of prior conferences, for the occasional deficiencies in judicial craftsmanship, and for the apparent inertia in dealing with social issues, can be laid at the door of the Court. However minor these latter factors may be compared with the influence of the outmoded appellate structure saddled on the Court by constitution and statute, they deserve brief comment.

That a prisoner has a right to a post-conviction hearing when he alleges denial of due process in his conviction is a notion rooted deep in constitutional liberty. The Court's attitude toward the social consequences of its decisions is indicated by the virtually complete inability of a prisoner to obtain such a hearing in Illinois. Although some procedure must be established to prevent crowding the dockets with fabricated or inadequate petitions, the existing method, which requires the prisoner to present his application for consideration seven to twelve times in order to escape the procedural maze of the state courts and secure his initial hearing on the merits in the federal courts, is totally inadequate. ${ }^{374}$ Adoption of some of the suggestions made in the Criminal Law Section might substantially improve the existing situation. ${ }^{355}$ In another field which involved fundamental political questions, the Court, last year, largely ignored the problems of religious liberty and the relationship of church and state by saying

${ }^{3{ }^{3} 3}$ Last year 48.8 per cent of the cases reaching the Supreme Court originated in the First Appellate District, which includes Chicago.

$3 \times 4$ See Criminal Law Section, at II8 supra.

375 Ibid., at $\mathrm{I29}-3 \mathrm{r}$ supra. 
only that church-financed public school religious "classes do not violate the freedom of conscience of any individual or group so long as the classes are conducted upon a purely voluntary basis." ${ }^{366}$ The Court's resistance to change is more clearly shown in private law. It clung to the strict old rule of mutuality in specific performance, ${ }^{377}$ refused to abate the purchase price where the vendor's wife refused to join in the deed, ${ }^{318}$ put a widow's old dower right ahead of her statutory share, ${ }^{3 \times 9}$ and declined to admit evidence of usage in construing the language of a deed. ${ }^{320}$ It limited the Workmen's Compensation remedy by strictly circumscribing the scope of employment. ${ }^{32 x}$

Less important are occasional inadequacies of judicial craftsmanship. Multiplication of the grounds for decision obscures the holdings of a few cases and may reflect the indefinite character of the issues in cases coming to the Court directly from trial courts. ${ }^{322}$ More important than multiple holdings as a means of avoiding sharp, definite decisions, the Court has some tendency to use alternative propositions in similar cases, emphasizing the one which will serve as a rationale for the decision. Thus in two zoning cases the Court employed the propositions, that a zoning ordinance is presumed to be valid and that a property owner may use his land as he desires limited only by a reasonable exertion of the police power, to achieve contrary results..$^{323}$ In construing statutes, the Court's work is a curious combination of extreme technicality as in its invalidation of several tax levies for failure to comply meticulously with the statutes, ${ }^{324}$ and the statesmanlike repair of omissions and inconsistencies in legisla-

${ }^{316}$ People ex rel. McCollum v. Board of Education of School District No. 7I, 396 Ill. I4, 7 I N.E. 2d I6I (I947), cert. granted 67 S. Ct. I524 (r947), discussed at I3r supra.

${ }_{327}$ Wloczewski v. Kozlowski, 395 Ill. 402, 70 N.E. 2d 560 (I946), discussed at I43 supra.

${ }_{318}$ Pearson v. Adams, 394 Ill. 39I, 68 N.E. $2 d 777$ (I946), discussed at I $_{4} 6$ supra.

${ }_{359}$ Bruce v. McCormick, 396 Ill. 482, 72 N.E. 2d 333 (I947), discussed at $x_{49}$ supra.

${ }^{320}$ Ambarann Corp. v. Old Ben Corp. 395 Ill. I54, 69 N.E. 2d 835 (1946), discussed at I45 supra.

${ }_{32 x}$ Public Service Co. v. Industrial Comm'n, 395 IIl. 238, 69 N.E. 2d 875 (I946), discussed at 155 supra.

32a See, for example, Wloczewski v. Kozlowski, 395 Ill. 402, 70 N.E. 2d 560 (I946), discussed at 143 supra.

3232700 Irving Park Building Corp. v. Chicago, 395 Ill. I38, 69 N.E. 2 d 827 (I946), noted in ${ }_{4}$ Univ. Chi. L. Rev. 718 (I947), discussed at 366 supra; DeBartolo v. Oak Park, 396 Ill. 404, 7 N.E. 2d 693 (I947), discussed at I37 supra.

324 See, for example, Saline Branch Drainage District v. Urbana-Champaign Sanitary District, 395 III. 26, 69 N.E. 2 d 25 I (1947), discussed at 140 supra. 
tion. ${ }^{325}$ Seldom during the year were precedents miscited. In one case, however, three of the cases cited contained facts different enough from the main case to make them doubtful authority for the Court's insistence on strict performance of a contract for the purchase of land. ${ }^{326}$ And in another case the Court cited a long line of cases all based upon a case in which an appropriation ordinance was filed instead of a tax ordinance, when the issue was whether filing the original tax ordinance instead of a copy invalidated the tax levy. ${ }^{327}$

The potential dangers of lack of conferences during the preparation of opinions have already been discussed. Although the method may be appropriate for the large numbers of insignificant cases reaching the Court as a result of inadequacies in the appellate structure, one-judge opinion writing may have serious consequences in important cases. The small number of dissents and special concurrences, and the infrequency with which the Court attempts to create patterns in the law, may be symptoms of the one-judge opinion. Even the remotest possibility that the decision of a case may depend upon which judge is assigned to write the opinion (though no case has been found in which it could be said that this occurred) calls for a revision of the Court's working habits. ${ }^{328}$

The greatest influence upon the totality of Illinois Supreme Court decisions is exerted by the Illinois Constitution and the Civil Practice Act. ${ }^{329}$ The large percentage of real property cases and the paucity of commercial cases is testimony of the anachronistic nature of the Constitution of I870. Preemption of the Court's time with trivial issues of law and complicated fact situations unsorted by intermediate appellate review is apparently one reason for what amounts, in most instances, to final review at the appellate court level of important litigation not entitled to mandatory Supreme Court review. It seems essential to overhaul an appellate review system which leaves much consequential commercial litigation to intermediate appellate courts in order to give review of right to cases incidentally involving title to a few rods of freehold. If the Court is to deal with more significant issues, it must be given a larger measure of control over the cases which it hears.

Much could be done by the legislature through revision of Section 75 of

325 Anderson v. Park Ridge, 396 Ill. 235, 72 N.E. 2 d 210 (1947), discussed at $x_{4}$ I supra.

${ }^{326}$ Johnson v. Riedler, 395 Ill. 4I2, 70 N.E. 2 d 570 (I946), discussed at 147 supra.

327 People ex rel. McWard v. Wabash R. Co., 395 Ill. 243, 70 N.E. 2 d 36 (1946), discussed at 140 supra.

${ }^{328}$ Compare discussion at 166-68 supra.

${ }^{329}$ See discussion of the Court's constitutional and statutory framework at Io8 supra. 
the Civil Practice Act. If direct review of right by the Supreme Court were eliminated, it is probable that many of the more trivial cases would not survive review in the appellate courts. The least that might be accomplished by so revising the Civil Practice Act is that issues would be clarified at a lower level, and the Supreme Court might then make rules of law without being compelled to digest records complicated by intricate facts.

Finally, it must be recognized that the Supreme Court will never have the requisite measure of control over its docket until the Judiciary Article of the Constitution of Illinois is amended. Only a constitutional amendment can eliminate appeals of right in litigation of no importance in the twentieth century. 